Gondwana Research

August 2016, Volume 36, Pages 503-522

http://dx.doi.org/10.1016/i.gr.2015.08.005

http://archimer.ifremer.fr/doc/00278/38962/

(C) 2015 International Association for Gondwana Research. Published by

Elsevier B.V. All rights reserved.

\title{
Evolution of neodymium isotopic signature of seawater during the Late Cretaceous: Implications for intermediate and deep circulation
}

\author{
Moiroud Mathieu ${ }^{1}$, Pucéat Emmanuelle ${ }^{1,{ }^{*}}$, Donnadieu Yannick ${ }^{2}$, Bayon Germain ${ }^{3}$, Guiraud Michel ${ }^{1}$, \\ Voigt Silke ${ }^{4}$, Deconinck Eric ${ }^{1}$, Monna Fabrice ${ }^{5}$
}

${ }^{1}$ UMR CNRS 6282 Biogéosciences, Université de Bourgogne, 6 bd Gabriel, 21000 Dijon, France

2 UMR CEA/CNRS, 1572 Laboratoire des Sciences du Climat et de l'Environnement, CE Saclay, Orme

des Merisiers, Bât. 701, 91191 Gif sur Yvette Cedex, France

${ }^{3}$ Département Géosciences Marines, Ifremer, 29280 Plouzané, France

${ }^{4}$ Institute of Geosciences, Goethe-Universität Frankfurt, Altenhöferallee 1, 60439 Frankfurt, Germany

${ }^{5}$ UMR CNRS 6298 ArTeHiS, Université de Bourgogne, 6 bd Gabriel, 21000 Dijon, France

*Corresponding author : Emmanuelle Pucéat, email address : emmanuelle.puceat@u-bourgogne.fr

\begin{abstract}
:
Neodymium isotopic compositions $(\varepsilon N d)$ have been largely used for the last fifty years as a tracer of past ocean circulation, and more intensively during the last decade to investigate ocean circulation during the Cretaceous period. Despite a growing set of data, circulation patterns still remain unclear during this period. In particular, the identification of the deep-water masses and their spatial extension within the different oceanic basins are poorly constrained. In this study we present new deep-water $\varepsilon N d$ data inferred from the $\mathrm{Nd}$ isotope composition of fish remains and Fe-Mn oxyhydroxide coatings on foraminifera tests, along with new $\varepsilon N d$ data of residual (partly detrital) fraction recovered from DSDP sites 152 (Nicaraguan Rise), 258 (Naturaliste Plateau), 323 (Bellinghausen Abyssal Plain), and ODP sites 690 (Maud Rise) and 700 (East Georgia Basin, South Atlantic). The presence of abundant authigenic minerals in the sediments at sites 152 and 690 detected by XRD analyses may explain both middle rare earth element enrichments in the spectra of the residual fraction and the evolution of residual fraction $\varepsilon N d$ that mirror that of the bottom waters at the two sites. The results point towards a close correspondence between the bottom water $\varepsilon N d$ values of sites 258 and 700 from the late Turonian to the Santonian. Since the deep-water Nd isotope values at these two sites are also similar to those at other proto-Indian sites, we propose the existence of a common intermediate to deep-water water mass as early as the mid-Cretaceous. The water mass would have extended from the central part of the South Atlantic to the eastern part of proto-Indian ocean sites, beyond the Kerguelen Plateau. Furthermore, data from south and north of the Rio Grande Rise-Walvis Ridge complex (sites 700 and 530) are indistinguishable from the Turonian to Campanian, suggesting a common water mass since the Turonian at least. This view is supported by a reconstruction of the Rio Grande Rise-Walvis Ridge complex during the Turonian, highlighting the likely existence of a deep breach between the Rio Grande Rise and the proto-Walvis Ridge at that time. Thus deep-water circulation may have been possible between the different austral basins as early as the Turonian, despite the presence of potential oceanic
\end{abstract}


barriers. Comparison of new seawater and residue $\varepsilon N d$ data on Nicaraguan Rise suggest a westward circulation of intermediate waters through the Caribbean Seaway during the Maastrichtian and Paleocene from the North Atlantic to the Pacific. This westward circulation reduced the Pacific water influence in the Atlantic, and was likely responsible for more uniform, less radiogenic $\varepsilon N d$ values in the North Atlantic after $80 \mathrm{Ma}$. Additionally, our data document an increasing trend observed in several oceanic basins during the Maastrichtian and the Paleocene, which is more pronounced in the North Pacific. Although the origin of this increase still remains unclear, it might be explained by an increase in the contribution of radiogenic material to upper ocean waters in the northern Pacific. By sinking to depth, these waters may have redistributed to some extent more radiogenic signatures to other ocean basins through deep-water exchanges.

\section{Graphical abstract}

A Cenomanian-Turonian interval (100.5 - $89.8 \mathrm{Ma})$

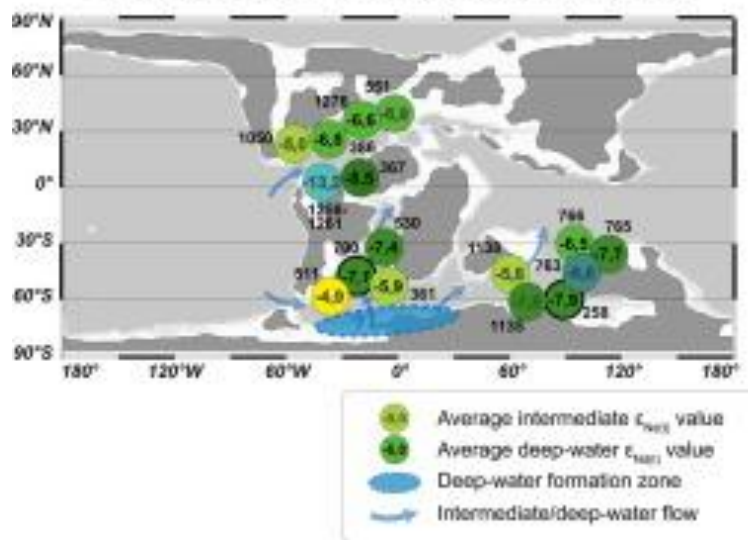

B Campanian-Maastrichtian interval $(83.6$ - $66.0 \mathrm{Ma})$

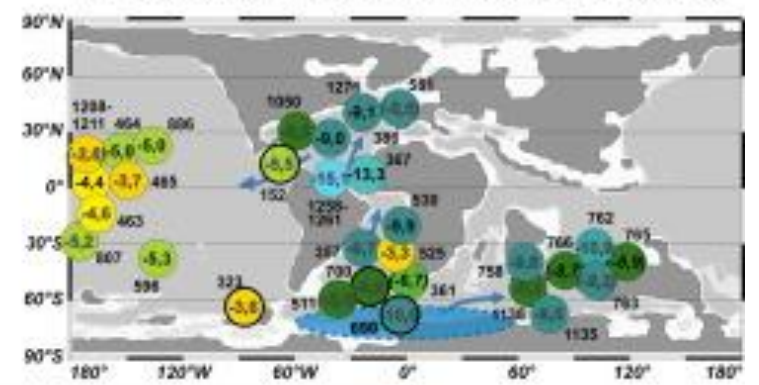

Elevation (m)

$-2000-500 \quad 0$

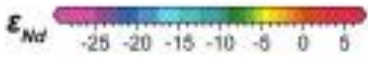

\section{Highlights}

- New neodymium isotope analyses used to investigate Late Cretaceous oceanic circulation. Signature of intermediate to deep-water masses identified. Single deep-water source to South Atlantic and Indian sector since Turonian.

Keywords : Cretaceous, neodymium isotopes, ocean circulation, Southern Ocean 


\section{Introduction}

Climatic variations affecting the Cretaceous have been extensively documented through paleontological records, isotopic analyses and model simulations (Hallam, 1985; Barron et al., 1995; Huber et al., 1995; Poulsen et al., 2001; Otto-Bliesner et al., 2002; Pucéat et al., 2003; Donnadieu et al., 2006; Hay et al., 2008; Craggs et al., 2012). Among the main features of this time period, climate reconstructions show the occurrence of extreme warmth during the Cenomanian-Turonian interval, followed by a long-term cooling during the Late Cretaceous, particularly accelerated during the Campanian (Huber et al., 1995; Pucéat et al., 2003; Steuber et al., 2005; Friedrich et al., 2012). The Late Cretaceous is also marked by a deepening of the Central Atlantic Gateway, the enlargement of the North and South Atlantic basins, and the first stages of Tethyan Ocean narrowing (Jones et al., 1995; Sewall et al., 2007; Cramer et al., 2009; Friedrich et al., 2012). It has been suggested that these changes in climate and paleogeography during the Late Cretaceous may have caused substantial reorganisation of ocean circulation modes, possibly related in turn to the disappearance of the Oceanic Anoxic Events (OAEs) after the Cretaceous (e.g. Robinson et al., 2010; Robinson and Vance, 2012).

In order to investigate the ocean circulation patterns and their evolution during the Late Cretaceous, neodymium isotope data have been recently generated for this period of time 
(e.g. MacLeod et al., 2008; Robinson et al., 2010; Martin et al., 2012; Murphy and Thomas, 2013; Voigt et al., 2013). The neodymium isotopic composition $\left({ }^{143} \mathrm{Nd} /{ }^{144} \mathrm{Nd}\right.$ ratio, expressed as $\varepsilon_{\mathrm{Nd}}$ ) of past seawater, typically reconstructed from that of fish remains or authigenic $\mathrm{Fe}-\mathrm{Mn}$ marine oxides, has a demonstrated potential for tracking ocean circulation in both modern and ancient oceans (e.g. Frank, 2002; Goldstein and Hemming, 2003; Thomas, 2004; Piotrowski et al., 2008; Robinson et al., 2010). The distribution of neodymium isotopes in seawater is mainly controlled by dissolved Nd inputs, provided by subaerially exposed rocks on the continents, and exported to the oceans through weathering and fluvial transport (Piepgras et al., 1979; Goldstein and O'Nions, 1981; Frank, 2002; Tachikawa et al., 2003). Differences in mean age and geochemical composition (crustal vs. mantellic) of the rocks surrounding the oceanic basins strongly influence the isotopic composition of nearby surface seawaters. This particular isotopic signature is subsequently exported from upper ocean waters to depth in areas of deep-water formation, or during particle settling through the water column. The estimated oceanic residence time of neodymium ( 300 to 600 years) is shorter than the oceanic mixing rate of about 1500 years (Broeker and Peng, 1982; Frank, 2002; Tachikawa et al., 2003; Arsouze et al., 2009). These characteristics lead to interbasinal heterogeneities in the $\varepsilon_{\mathrm{Nd}}$ composition of water masses, with $\mathrm{Nd}$ isotopic signatures inherited from the geographical provenance (Piepgras and Wasserburg, 1982). Hence in modern deep-water circulation, the unradiogenic signature of North Atlantic Deep Water (NADW; $\varepsilon_{\mathrm{Nd}} \sim-13.5 \varepsilon-$ units) derives from the contribution of $\mathrm{Nd}$ from Archean and Proterozoic continental rocks in northern Canada and Greenland (Piepgras and Wasserburg, 1987; Lacan and Jeandel, 2005a, 2005b). In contrast, the Pacific Ocean has a more radiogenic composition $\left(\varepsilon_{\mathrm{Nd}}=0\right.$ to -5$)$ reflecting the weathering of young island arc volcanic materials (Piepgras and Jacobsen, 1988; Shimizu et al., 1994; Amakawa et al., 2004; 2009). These distinct signatures are subsequently exported by deep currents and modified through water mass exchange, as shown 
in the Southern Ocean where the mixing of both Atlantic and Pacific waters by the vigorous Antarctic Circumpolar Current (ACC) generates intermediate values $\left(\varepsilon_{\mathrm{Nd}} \sim-9 /-8\right)$ (Piepgras and Wasserburg, 1982; Jeandel, 1993; Rickli et al., 2009; Carter et al., 2012).

Despite the growing set of recently published paleoceanographic data, the deep-water circulation modes and their evolution during the Cretaceous period remain disputed (e.g. Frank et al., 2005; MacLeod et al., 2008; 2011; Friedrich et al., 2012; Martin et al., 2012; Murphy and Thomas, 2012; Robinson et al., 2010; Robinson and Vance, 2012; Murphy and Thomas, 2013; Voigt et al., 2013). During the Late Cretaceous, a long-term decrease in intermediate and deep-water $\varepsilon_{\mathrm{Nd}(\mathrm{t})}$ has been depicted at different sites of the Southern Ocean, the South Atlantic and the North Atlantic, from values of -5/-7 $\varepsilon$-units in the TuronianSantonian interval to -8/-10 $\varepsilon$-units in the Campanian-Turonian interval. This trend towards lower $\varepsilon_{\mathrm{Nd}}$ values has been interpreted as the consequence of the onset or intensification of deep-water production of Southern Component Water (SCW) in the southern Atlantic or Indian Ocean (Robinson et al., 2010; Robinson and Vance, 2012; Murphy and Thomas, 2013; Voigt et al., 2013). Propagation of this unradiogenic signal into the different oceanic basins would then have been favoured by better communications between oceanic basins due to the subsidence of tectonic barriers and a more vigorous ocean circulation (Robinson et al., 2010; Robinson and Vance, 2012; Murphy and Thomas, 2013; Voigt et al., 2013). Previous studies have also mentioned the progressive subsidence of Large Igneous Provinces (LIPs) and hot spots in the South Atlantic and Indian oceans during the Late Cretaceous to explain the decreasing trend in Nd isotope compositions (Murphy and Thomas, 2013). Indeed, the drowning of mantle-derived material below sea-level would have reduced the subaerial weathering of radiogenic Nd in the Southern Ocean. Alternatively, initiation or intensification of unradiogenic deep-water production in the northern Atlantic has also been proposed to explain the observed Nd isotope trends (MacLeod et al., 2011; Martin et al., 2012). Amongst 
other potential sources of deep-waters in the Late Cretaceous and Paleogene, the North and South Pacific areas have been proposed in different studies based on Nd isotope data and on model simulations (Thomas, 2004; Frank et al., 2005; Hague et al., 2012; Murphy and Thomas, 2012; Thomas et al., 2014). Alternatively, water sinking to abyssal depth has been suggested to occur in the equatorial Atlantic near Demerara Rise during most of the Late Cretaceous based on neodymium isotopes studies (MacLeod et al., 2008; 2011).

Therefore, there is still no consensus on the origin of the deep-waters filling the different oceanic basins and the circulation changes during the Late Cretaceous. Part of these uncertainties arises from the still insufficient spatial distribution of deep-water $\mathrm{Nd}$ isotopic data in the South Atlantic, Indian Ocean, and in the southern Pacific that has been suggested as a potential area of deep-water production. Key passages like the Caribbean Seaway, which potentially linked the North Atlantic and Pacific Oceans, are also devoid of any Cretaceous $\varepsilon_{\mathrm{Nd}}$ data. Here we present new early Turonian to late Paleocene ( 93 to $\left.58 \mathrm{Ma}\right)$ seawater $\mathrm{Nd}$ isotope records derived from fish debris and foraminifera tests from different Deep Sea Drilling Project (DSDP) and Oceanic Drilling Project (ODP) sites, to reconstruct the Nd isotopic composition of intermediate (500-2000 m) to deep (beneath $2000 \mathrm{~m}$ ) water masses in the South Hemisphere and in the Caribbean Seaway. We targeted sites from the South Atlantic and proto-Indian Ocean (DSDP Site 258 and ODP sites 690 and 700), some of which (sites 258 and 700) had never been investigated for Nd isotope studies, to (i) constrain the extension of the SCW and its communication between the Late Cretaceous oceanic basins, and (ii) discuss the possible influence of oceanic barriers such as the Walvis Ridge-Rio Grande Rise system on deep-water circulation. Additional $\varepsilon_{\mathrm{Nd}}$ data were provided from a southern Pacific site (DSDP Site 323) to decipher potential areas of deep-water formation in this region. Finally, we present the first Nd isotope data from the Caribbean region (Site 152) to track the water exchange between the North Atlantic and Pacific oceans during the Late 
Cretaceous-Early Paleocene. These results are then compared to published $\varepsilon_{\mathrm{Nd}}$ data from the literature.

\section{Site selection and description}

For all sites, the age models are presented in the Supplementary Information. DSDP Leg 15 Hole 152 is located on the lower flanks of the Nicaragua Rise, and was drilled at a modern depth of $3899 \mathrm{~m}$ (Fig. 1). The good preservation of calcareous fossils suggests that the sediments at Site 152 were deposited at a bathyal depth, well above the calcium carbonate compensation depth (CCD). The samples were collected in the interval 204.51-453.91 m below sea floor (mbsf) (core sections 6-3/50-52 cm to 21-1/90-92 cm), consisting of white micritic chalk (Edgar et al., 1973). These sediments are rich in foraminifera and nannofossils, which indicate ages from late Campanian to Paleocene (Hay and Beaudry, 1973; Premoli Silva and Bolli, 1973). Though volcanic ash beds are persistent throughout this hole, our samples were carefully selected outside these levels.

DSDP Leg 26 Hole 258 is located on the northern flank of the Naturalist Plateau, the westward extension of the continental margin of southwestern Australia, at a modern depth of 2793 m (Fig. 1). Palaeontological observations indicate similar paleo-water depth, in the 2500-3000 m range, within or above the CCD during the beginning of the Late Cretaceous in a pelagic environment (Davies et al., 1974). The samples were collected in the interval between 125.51 and $255.40 \mathrm{mbsf}$ (core sections 5-2/50-52 $\mathrm{cm}$ to $13-2 / 39.5-41.5 \mathrm{~cm}$ ). The lithology consists of monotonous greyish chalk encompassing the first half of the Upper Cretaceous. The micritic sediments yield well-preserved Early Santonian foraminifera in the upper part of the hole (above core 10), whereas the lower Turonian to the Coniacian part is richer in coccoliths with fewer, poorly preserved foraminifera. Upper Cretaceous sediments 
are missing due to an important hiatus until the Upper Miocene. Precise ages are difficult to estimate due to the low foraminiferal diversity with scarce index forms in the sampled interval, although nannofossil biozones were better constrained (Davies et al., 1974; Thierstein, 1974).

DSDP Leg 35 Hole 323 lies at a modern depth of 5004 m on the Bellingshausen Abyssal Plain, north of the base of the Antarctic continental rise (Fig. 1). Our samples were collected in the interval between 663.21 and $700.11 \mathrm{mbsf}$ (core sections $15-6 / 70-72 \mathrm{~cm}$ to 18 5/110-112 cm). The sampled interval contains yellow to brown pelagic clay with arenaceous foraminifera, suggesting a quiet and deep environment below the $\mathrm{CCD}$, at bathyal depths (Hollister et al., 1976). Fluctuations of the CCD depth allowed preservation of the nannofossil content below and above the sampled interval, indicating Maastrichtian to early Paleocene ages for our samples (Haq, 1976; Weaver et al., 1976).

ODP Leg 113 Hole 690C was drilled at 2914 m below sea level on the southwestern flank of Maud Rise, a volcanic ridge in the eastern Weddell Sea (Fig. 1). Shallower conditions were estimated for the Late Cretaceous, with a lower to mid-bathyal depth ( 1000-2000 m) in a pelagic, open-ocean environment (Barker et al., 1988). The samples analysed for this study were chosen between 204.41 and $315.81 \mathrm{mbsf}$ (core sections 11-1/20-22 $\mathrm{cm}$ to 22-3/70-72 $\mathrm{cm})$. The interval comprises nannofossil ooze-bearing chalk with contributions of terrigenous sediments and volcanic glass, with muddy chalk and calcareous mudstone in the CampanianMaastrichtian interval (281.10 to $317.00 \mathrm{mbsf}$ ), muddy nannofossil ooze with foraminifera in the higher Maastrichtian (252.50 to $281.10 \mathrm{mbsf}$ ), and predominantly nannofossils chalk in the uppermost Maastrichtian and Paleocene (177.30 to $252.50 \mathrm{mbsf}$ ). Age estimates derive from magnetostratigraphic studies and detailed nannofossil and foraminiferal biostratigraphy (Barker et al., 1988; Hamilton, 1990; Huber, 1990). 
ODP Leg 114 Hole 700B is located on the northeastern slope of the Northeast Georgia Rise, in the western region of the East Georgia Basin (South Atlantic), at a modern depth of $3601 \mathrm{~m}$ (Fig. 1). Paleo-depth estimates lie between 1500 to $2500 \mathrm{~m}$ for the Late Cretaceous (Ciesielski et al., 1988). Our samples were selected between 276.80 and 480.22 mbsf (core sections $30-1 / 79-80 \mathrm{~cm}$ to $54-1 / 71-72.5 \mathrm{~cm}$ ), in an interval mainly composed of chalk and limestone (Ciesielski et al., 1988). The lower unit consists of alternating micritic limestone and clayey limestone attributed to the Turonian-Campanian, with occasional layers enriched in volcanic ash (441.5 to $489.0 \mathrm{mbsf}$ ), although our samples were not taken in these particular levels. The lithology of the Campanian-Maastrichtian sediments is similar but without volcanoclastic layers (359.0 to $441.5 \mathrm{mbsf}$ ). An important hiatus, up to $9 \mathrm{Ma}$, affects most of the Campanian. Nannofossil-bearing micritic limestone (319.0 to $359 \mathrm{mbsf}$ ) has been assigned to the Maastrichtian-early Paleocene. Above this unit, the lithology of the Paleocene sediments consists of nannofossil-bearing micritic indurated chalk (228.50 to $319.0 \mathrm{mbsf}$ ). Age estimates are based on biostratigraphic and paleomagnetic data (Ciesielski et al., 1988. Huber, 1991).

\section{Material and analytical methods}

For each sample, several cubic centimetres of bulk sediment were briefly soaked and agitated in distilled water, and then washed and sieved. Foraminifera tests and fish remains were handpicked from the $>63 \mu \mathrm{m}$ fraction under a binocular microscope. About 20 to 200 $\mathrm{mg}$ of foraminifera tests and 0.2 to several $\mathrm{mg}$ of fish debris were collected for each sample. A total of 10 foraminifera samples and 2 fish debris samples were recovered for Site 152; 2 foraminifera samples and 4 fish debris samples for Site 258; 3 fish debris samples for Site323; 19 foraminifera samples and 2 fish debris samples for Site 690; and 10 foraminifera samples 
for Site 700. For all foraminifera samples, only individuals with hyaline calcareous tests were selected. They mostly belong to planktonic genera (Globotruncana spp., Globigerina spp. and Heterohelix spp.) although some benthic foraminifera tests (mainly Gyroidinoides spp., Neoeponides spp. and Praebulimina spp.) were additionally picked in samples with low planktonic foraminiferal content. These samples are identified in Tables 1 and 2 by an asterisk. When possible, both foraminifera and fish remains were extracted from the same samples of sieved sediments to compare the Nd isotope signal inferred from both materials.

The fish debris were subsequently washed with distilled water in an ultrasonic bath to remove potential clay particles. No reductive/oxidative procedure was performed, as previous studies have shown that rigorously oxidative/reductive cleaned and uncleaned fish debris yield very close Nd isotope signatures (Martin et al., 2010; Hague et al., 2012). Fish remains were subsequently dissolved in twice-subboiled concentred $\mathrm{HCl}$. The foraminifera samples were dissolved at room temperature using a mixed $0.05 \mathrm{M}$ hydroxylamine hydrochloride $(\mathrm{HH})$ and $15 \% \mathrm{v} / \mathrm{v}$ acetic acid (AA) solution, after a procedure adapted from Bayon et al. (2002), and are referred to as 'foraminifera HH-extraction' from here on.

In order to analyse the rare-earth element (REE) content and the $\mathrm{Nd}$ isotopic signature of the detrital fraction, 6 bulk rock samples were selected from Site 152, and 6 samples from Site 690. Two additional bulk rock samples from Site 690 and two samples from Site 700 were analysed for their REE content only. Each bulk rock sample was decarbonated with $2 \%$ v/v acetic acid. Some samples were reacted with a solution of $15 \%$ AA and 1M HH under agitation (identified by the mention 'HH' in Table 2). Alkaline fusion was then performed on dried bulk residues after addition of sodium peroxide $\left(\mathrm{Na}_{2} \mathrm{O}_{2}\right)$ and sodium hydroxide $(\mathrm{NaOH})$ by heating at $650^{\circ} \mathrm{C}$ for $12 \mathrm{~min}$ in glassy carbon beakers, following the protocol described in Bayon et al. (2009). Addition of distilled water to the obtained melt leads to Fe-oxyhydroxide co-precipitation in basic solution, absorbing the REEs. The solution is subsequently 
centrifuged, rinsed with distilled water after removal of the supernatant, and dried. The residue is ultimately dissolved in $4 \mathrm{M} \mathrm{HCl}$.

Aliquots of dissolved foraminifera, dissolved fish debris and alkaline fusion Feoxyhydroxide residual fractions were used to determine REE abundances. The solutions were analysed on an Element2 inductively coupled plasma sector field mass spectrometer (ICPSFMS) at the Pôle Spectrométrie Océan (PSO, Brest, France). The analyses were performed in low-resolution mode but corrected from oxide and hydroxide interferences by analysing deionised (Milli-Q) water and reference solutions of $\mathrm{Ba}+\mathrm{Ce}, \mathrm{Pr}+\mathrm{Nd}$ and $\mathrm{Sm}+\mathrm{Gd}+\mathrm{Tb}$ (Barrat et al., 1996; Bayon et al., 2009). Sample elemental concentrations were calculated using the Tm spike addition method (Barrat et al., 1996; Bayon et al., 2009). The sample analyses were calibrated against an unspiked BHVO-2 reference solution. Analysis of the reference solution was run every three samples to assess instrumental drift. Elemental concentrations were then calculated using the sample masses and the amount of Tm spike added. The results of the REE analyses are reported on Table 2.

$\mathrm{Nd}$ purification of all the samples prior to isotopic analyses followed a modified version of the method developed by Pin and Zalduegi (1997). The remaining solution of leached foraminifera, dissolved fish debris and alkaline fusion residues were placed in a first set of columns $(20 \mathrm{~mL})$ packed with Bio-Rad AG50W-X8 resin. The Fe content was removed by washing the columns with $4 \mathrm{M} \mathrm{HCl}$. The elution of the REEs was performed with progressive addition of $6 \mathrm{M} \mathrm{HNO}_{3}$. The solutions were subsequently transferred to a second set of columns ( $2 \mathrm{~mL}$ ) containing Ln resin (Eichrom), where the $\mathrm{Nd}$ content was eluted with $0.25 \mathrm{M} \mathrm{HCl}$. Nd isotope measurements were performed at the PSO (Brest, France) on a Neptune multi-collector inductively coupled plasma mass spectrometer (MC-ICP-MS, Thermo Fisher Scientific). Nd isotope ratios were corrected for mass discrimination by normalising to ${ }^{146} \mathrm{Nd} /{ }^{144} \mathrm{Nd}=0.7219$ using an exponential law. The corrected isotopic ratios 
were normalised to ${ }^{143} \mathrm{Nd} /{ }^{144} \mathrm{Nd}=0.512115$ for the JNdi-1 Nd standard (Tanaka et al., 2000). Analyses of the La Jolla Nd standard gave ${ }^{143} \mathrm{Nd} /{ }^{144} \mathrm{Nd}$ of $0.511862 \pm 0.000019$ (2 s.d., $\mathrm{n}=$ 21 ), which corresponds to an external reproducibility of $\sim 0.37 \varepsilon$-units. Procedural Nd blanks were typically less than $80 \mathrm{pg}$ and hence negligible compared to the $\mathrm{Nd}$ signals measured in this study. All ${ }^{143} \mathrm{Nd} /{ }^{144} \mathrm{Nd}$ values analysed on the MC-ICP-MS are reported in Table 1 . The $\mathrm{Nd}$ isotopic ratios are expressed with the epsilon notation $\left(\varepsilon_{\mathrm{Nd}}=\left[\left({ }^{143} \mathrm{Nd} /{ }^{144} \mathrm{Nd}\right)_{\text {sample }} /\left({ }^{143} \mathrm{Nd} /{ }^{144} \mathrm{Nd}\right)_{\mathrm{CHUR}}-1\right] * 10^{4}\right)$ corrected for the radioactive decay of ${ }^{147} \mathrm{Sm}$ to ${ }^{143} \mathrm{Nd}$ using the $\mathrm{Nd}$ and $\mathrm{Sm}$ concentrations determined for the same samples $\left({ }^{147} \mathrm{Sm} /{ }^{144} \mathrm{Nd}=\mathrm{Sm} / \mathrm{Nd}^{*} 0.6049\right)$, the absolute age $(\mathrm{t})$ of the studied sedimentary units, and the ${ }^{147} \mathrm{Sm}$ radioactive decay constant $\lambda\left(6.54 \times 10^{-12} \mathrm{an}^{-1}\right.$; Lugmair and Marti, 1977). The ${ }^{143} \mathrm{Nd} /{ }^{144} \mathrm{Nd}$ ratios measured in the samples were corrected for post-sedimentation decay of ${ }^{147} \mathrm{Sm}$ using their measured present-day values and ${ }^{147} \mathrm{Sm} /{ }^{144} \mathrm{Nd}$ ratios. The CHUR (CHondritic Uniform Reservoir) ${ }^{143} \mathrm{Nd} /{ }^{144} \mathrm{Nd}$ ratio was corrected using a present-day value of 0.512630 and a ${ }^{147} \mathrm{Sm} /{ }^{144} \mathrm{Nd}$ ratio of 0.1960 (Bouvier et al., 2008). Age estimates (t) of the samples were calculated using stratigraphical models for each site, with published biostratigraphic/magnetostratigraphic data as tie-points and corresponding numerical ages from the GTS2012 (Gradstein et al., 2012). Details of the age model calculations are given in the Supplementary information.

X-ray powder diffraction (XRD) was performed on the bulk sediments samples analysed in this work for their $\varepsilon_{\mathrm{Nd}}$ and REE patterns, in order to characterise the mineralogical composition of their detrital fraction at sites 152, 690 and 700. The clay mineral assemblages were also determined by XRD on oriented mounts of non-calcareous clay-sized particles (see Supplementary information for details on procedures and results). These analyses reveal a dominance of authigenic smectite and clinoptilolite derived from the volcanic inputs. 
In this study, we also present a compilation of intermediate and deep-water $\mathrm{Nd}$ isotope data. To detect the possible presence of multiple change points in terms of mean within the $\varepsilon_{\mathrm{Nd}}$ time series, statistical treatment was performed using the free R software (R Development Core Team, 2008; http://www.r-project.org/) together with the changepoint package (Killick and Eckley, 2014). The underlying idea is to treat each set of $n \varepsilon_{\mathrm{Nd}}$ measurements (for each oceanic basin) as ordered (ranked) sequences of data and to find a point, say $p$, for which $\left\{\varepsilon_{\mathrm{Nd} 1}, \ldots, \varepsilon_{\mathrm{Ndp}}\right\}$ and $\left\{\varepsilon_{\mathrm{Ndp}+1}, \ldots, \varepsilon_{\mathrm{Ndn}}\right\}$ differ in terms of means. By extending this approach to multiple, say $m$, change points, the sequence is split into $m+1$ segments. The algorithm used for calculation provides the optimal number and the positions (statistically significant, although approximate) where potential changes occur. More details can be found in Sen and Srivastava (1975). It should be noted that, formally, such an algorithm is designed to identify $m$ breaks in a set $m+1 \mathrm{~N}(\mu, \sigma)$ normal distributions, in other words in a discontinuous sequence of data. Obviously, the $\varepsilon_{\mathrm{Nd}}$ evolution through time is known to be continuous by nature. A procedure based on detection of changes in slopes (e.g. SiZer or segmentation by piecewise-linear relationships) would have been therefore theoretically better adapted. These slope-based methods require a roughly homogenous distribution of samples over time that is not the case here. As a result, the changepoint approach described above was preferred to identify the main, if approximate, changes over the periods of interest (increase or decrease of $\left.\varepsilon_{\mathrm{Nd}}\right)$.

\section{Results}

\subsection{REE spectra}

REE concentrations for HH-extractions of foraminifera are quite low, typically in the $0.1 \mathrm{ppm}$ up to few ten of ppm range. Residual fractions display significantly higher 
concentration in REEs. Fish debris yielded the highest REE concentrations, which can reach several thousands of ppm (Table 2).

At all sites, the fish debris samples exhibit shale-normalised REE patterns (PAAS; Taylor and McLennan, 1985) characterised by an enrichment in middle rare earth elements (MREEs) and a negative cerium (Ce) anomaly (Fig. 2). At sites 152 and 700, HH-extractions of foraminifera display a REE pattern enriched in heavy rare earth elements (HREE), with a pronounced negative Ce anomaly at Site 152, and a weaker anomaly at Site 700. At sites 258 and 690, HH-extractions of foraminifera display shale-normalised REE patterns that are either characterised by HREE or MREE-enrichment, with a pronounced negative Ce anomaly at Site 258 and a weak or absent Ce anomaly at Site 690. Residual fraction samples are characterised by moderately MREE- to moderately HREE-enriched patterns at Site 152, and only MREEenriched spectra at Site 690.

\subsection{Neodymium isotopes}

Samples from sites 152 and 323 exhibit the most radiogenic $\varepsilon_{\mathrm{Nd}(\mathrm{t})}$ values, ranging from $\sim-3$ to -5.5 E-units for Site 323, and from $\sim-2$ to $\sim-6$ for Site 152 (Fig. 3). The $\varepsilon_{\mathrm{Nd}(\mathrm{t})}$ values of the two fish debris samples from Site 152 are similar to those of coeval foraminifera $\mathrm{HH}$ extractions. The $\varepsilon_{\mathrm{Nd}(\mathrm{t})}$ values of both materials seem to increase from values around -6 to $-5 \varepsilon-$ units during the Maastrichtian to values up to about -3.2 $\varepsilon$-units in the Danian, before decreasing down to $5.1 \varepsilon$-units in the Thanetian, although this is based on one value only (Fig. 3). $\varepsilon_{\mathrm{Nd}(\mathrm{t})}$ values of the residual fraction follow the same trend as that defined by fish and foraminifera $\mathrm{HH}$-extraction, with values offset by about $1.5 \varepsilon$-units toward more radiogenic values (Fig. 3). Conversely, the fish debris $\varepsilon_{\mathrm{Nd}(\mathrm{t})}$ values from Site 323 show a decreasing trend from $\sim-3$ to $-5.5 \varepsilon$-units from the beginning of the Maastrichtian to the Danian, although this trend should be considered with caution as it is based on 3 values only. 
At Site 258 , the $\varepsilon_{\mathrm{Nd}(\mathrm{t})}$ values of the fish remain samples are between $\sim-9$ and $-7 \varepsilon$-units. The foraminifera $\mathrm{HH}$-extraction $\varepsilon_{\mathrm{Nd}(\mathrm{t})}$ values are similar to those of fish remains from the same sediment sample, with small differences ( 0.2 and $0.4 \varepsilon$-units) toward less radiogenic values.

The foraminifera $\mathrm{HH}$-extractions at Site 690 yield more unradiogenic $\varepsilon_{\mathrm{Nd}}$ values from $\sim-11.5$ to $-8.5 \varepsilon$-units. Most of the HH-extractions of foraminifera yield values in the -9.7 to 10.7 range for the Campanian and Maastrichtian, although two samples exhibit more unradiogenic values of -11.2 and -11.6. The Paleocene samples tend to display more radiogenic values ranging from -8.6 to $-9.3 \varepsilon$-units, with the exception of one sample that exhibit an unradiogenic value of $-10.7 \varepsilon$-units. The $\varepsilon_{\mathrm{Nd}(\mathrm{t})}$ values of the two fish remains samples display slightly more radiogenic values than coeval foraminifera $\mathrm{HH}$-extractions, with differences of +0.42 and $+0.70 \varepsilon$-units. The detrital fraction values exhibit systematically more radiogenic values than corresponding foraminifera $\mathrm{HH}$-extractions by $\sim 1$ to $1.5 \varepsilon$-units, except for one Campanian sample that gave almost identical values. Similarly to the fish and foraminifera $\mathrm{HH}$-extraction samples, the residues display more radiogenic values in the Paleocene than during the Campanian-Maastrichtian.

At Site 700, the foraminifera $\mathrm{HH}$-extractions exhibit $\varepsilon_{\mathrm{Nd}(\mathrm{t})}$ values between $\sim-9$ and -6.5 $\varepsilon$-units. They define a decrease during the Late Cretaceous, from values in the range of -6.5 to $-8 \varepsilon$-units in the Coniacian-Santonian interval down to minimum values of -9.1 in the early Maastrichtian. An increase of $\mathrm{Nd}$ isotope values is then recorded by foraminifera $\mathrm{HH}$ extractions with values reaching - $7 \varepsilon$-units in the Danian. One data point from the Selandian gave a lower value of -8.3 $\varepsilon$-units.

\section{Discussion}




\subsection{Significance of the Nd isotope signal of the different fractions}

The shale-normalised HREE/LREE and MREE/MREE* ratios allow quantitative comparison of the obtained REE patterns to data from the literature. HREE/LREE represents the ratio between the sum of the PAAS-normalised concentrations (N) of Tm, Yb, and Lu (HREE) and La, Pr, and Nd (LREE); MREE/MREE* stands for the ratio of MREE (the sum of the concentrations of Gd, Tb, and Dy) to MREE* (the average of HREE and LREE) (Martin et al., 2010; modified from Haley et al., 2004; Fig. 4 and Table 2). Because Tm was used as a spike for REE concentration and was not measured in this work, (Tm)N concentrations were estimated as $(\mathrm{Er}+\mathrm{Yb}) \mathrm{N} / 2$. The MREE/MREE* ratio allows quantification of the extent of MREE bulge in REE patterns, and HREE/LREE the quantification of the HREE enrichment over LREE.

The REE patterns of fish remains analysed in this study display the typical spectrum of marine biogenic apatite recovered from deep-sea environments, with an enrichment in MREE and a negative Ce anomaly (Martin et al., 2010). Their shale-normalised ratios plot in the domain defined by previously published fish remains REE data (Fig. 4-B). Importantly, they reveal MREE/MREE* ratios that are much lower than those of 'bell-shaped' REE spectra of Triassic fish remains and Devonian conodonts that are systematically above 4 (Fig. 4-A), a pattern interpreted to reflect the impact of late diagenesis (Reynard et al., 1999). This argues for good preservation of the initial REE signal of fish remains analysed in this study. Fish remains have been shown to integrate the $\mathrm{Nd}$ isotope composition of bottom seawater, without fractionation, during early diagenetic processes at the sediment-water interface (Bernat, 1975; Wright et al., 1984; Shaw and Wasserburg, 1985; Martin and Haley, 2000; Martin and Scher, 2004). As a result, we consider the Nd isotope signal of the fish remains samples analysed in this study to reflect the $\mathrm{Nd}$ isotope composition of bottom seawater. 
Fe-Mn oxides coating planktonic foraminifera have been used in several studies to reconstruct the $\mathrm{Nd}$ isotope composition of bottom waters. Leaching foraminifera presents the advantage of reducing potential silicate contamination problems that may be associated in some cases with bulk sediment leaches. In our study the HH-extractions of foraminifera display REE patterns either enriched in MREE - resembling those of Fe-Mn oxides (Fig. 2; Bayon et al., 2004), or enriched in HREE - resembling those of seawater and carbonates, as extracted for instance from acetic acid leaches of bulk sediments (Fig. 4; Martin et al., 2010). It has been demonstrated that authigenic oxides act as major $\mathrm{Nd}$ carriers in planktonic foraminifera (Roberts et al., 2010; Elmore et al., 2011; Roberts et al., 2012; Tachikawa et al., 2013). Roberts et al. (2012) showed that (i) 80\% of the $\mathrm{Nd}$ in planktonic foraminifera from plankton tows and sediment traps is associated to authigenic metal oxides and organic matter, (ii) $\mathrm{Nd}$ isotope ratios underwent partial re-equilibration with ambient water as these phases remineralise during the settling of the tests through the water column, and (iii) REE concentrations of planktonic foraminifera may increases by up to 10-fold at the sedimentwater interface, acquiring an isotopic signature of bottom water. Importantly, these authors have demonstrated the formation of both authigenic oxides and authigenic micro-scale $\mathrm{MnCO}_{3}$ precipitates between the inner layers of calcite at or near the sediment-water interface. These neo-formed phases contribute significantly to elevated REE concentrations in foraminifera, with the relative proportion depending on pore-water oxygen concentration. As $\mathrm{HH}$ leaching both extracts the $\mathrm{Nd}$ signal of oxides and that of carbonates of foraminifera, a variable proportion of these two phases in the foraminifera tests analysed in this study may explain the occurrence of the two types of REE spectra observed in our foraminifera HHextractions. MREE-enriched spectra may occur when the REE signal is mostly carried by oxides, and HREE-enriched spectra when the REE signal is mostly carried by $\mathrm{MnCO}_{3}$ precipitates. Fe-Mn oxide coatings have been repeatedly shown to record the $\mathrm{Nd}$ isotope 
signature of bottom waters at the sediment-water interface (e.g. Rutberg et al., 2000;

Piotrowski et al., 2004; Gutjahr et al., 2007; Bayon et al., 2004; Martin et al., 2010; Roberts et al., 2010; Roberts et al., 2012), and it has been inferred by Roberts et al. (2012) that, despite recording a pore-water $\mathrm{Nd}$ isotope signature, potential smearing effects on the $\mathrm{MnCO}_{3}$ signal are not greater that the effect of bioturbation, and that this phase also recorded a bottom-water signal.

Another possibility is that the protocol of $\mathrm{HH}$-extraction we performed on the foraminifera samples is too gentle. It would results in dissolution of foraminifera calcite and potential $\mathrm{MnCO}_{3}$ precipitates, but also in incomplete dissolution of oxide coatings. If this is the case, such a protocol would still extract a seawater Nd signal, but may explain the occurrence of a REE spectra resembling carbonate REE spectra rather than an MREEenriched oxide spectra. It can be seen on Figure 4 that REE concentrations tend to be lower in the samples yielding a HREE-enriched spectra than in those yielding a MREE-enriched spectra, which would tend to support this hypothesis. In their study, Martin et al. (2010) showed that an acetic acid leach of bulk sediments only remove the carbonate fraction, producing HREE-enriched spectra typical of carbonates and seawater, similar to those obtained from our samples (Fig. 2-F). They indicated that such samples record the same deepwater $\mathrm{Nd}$ isotope values as those of fish teeth extracted from the same sediments, except for one sample with a very low carbonate content (less than $1 \% \mathrm{CaCO}_{3}$ ). The reason for this similarity is not clear, but considering the results of Roberts et al. (2012), it may be linked to $\mathrm{Nd}$ integration in authigenic $\mathrm{MnCO}_{3}$ precipitates. Therefore we are confident that the $\mathrm{Nd}$ isotope signal of the foraminifera $\mathrm{HH}$-extractions performed in our study reflect that of contemporaneous bottom seawater in the samples yielding MREE-enriched patterns, as well as for those yielding HREE-enriched spectra. This is further supported by the relatively good 
agreement between the $\mathrm{Nd}$ isotope values of fish remains and $\mathrm{HH}$-extraction of foraminifera analysed at the different sites in this study (Fig. 3).

The residual samples do not present a flat, shale-like REE pattern, but display patterns similar to those of our fish remains samples and MREE-enriched foraminifera HH-extraction, with negative Ce-anomalies and a bulge in MREE (Fig. 2-F and Fig. 4-D). Such characteristics preclude a purely detrital origin. Similar residue REE patterns presenting a negative Ce anomaly and a MREE enrichment have already been observed in samples from ODP cores (Martin et al., 2010; Fig. 2-F). Such patterns have been interpreted as incomplete removal of the authigenic oxide phase by the leaching procedures (Martin et al., 2010). Part of our residue samples has not undergone HH leaching but only a decarbonation, and these samples are therefore likely to represent a mix of detrital and Fe-Mn oxide fractions. More surprising are the results from samples that underwent decarbonation followed by the HHleaching step, which present REE patterns that are indistinguishable from those of the sediments that have been only decarbonated (Fig. 2-C). Application of a HH-leach too gentle to completely remove the oxides in the residue cannot be excluded, and if it is the case the residue $\mathrm{Nd}$ isotope signal would represent a mix between a purely detrital signal and a seawater signal. However, if these MREE-enriched spectra were reflecting the dominance of residual oxide REEs over the terrigenous-born REEs, we would have expected a substantial difference between the REE spectra of the residues that have undergone the HH-leach and those that have not.

An alternative explanation involves the presence of other authigenic minerals resistant to both decarbonation and $\mathrm{HH}$ leaching steps, such as neo-formed clay minerals and zeolites which can record REE patterns different from those of detrital shales (Chamley and BonnotCourtois, 1981; Dubinin, 2004; Karpoff et al., 2007; Fig. 2-F). Chamley and Bonnot-Courtois (1981) showed that authigenic clay minerals derived from the alteration of volcanic material 
were characterised by a depletion in LREE or an enrichment in MREE, and a negative Ce anomaly likely traducing the imprint of seawater (Fig. 2-F). The results of Karpoff et al. (2007) confirmed that authigenic clinoptilolite from residue of decarbonated sediments may also produce REE spectra with a MREE enrichment and a negative Ce anomaly (Fig. 2-F). XRD analyses show the abundant presence of authigenic smectite in the decarbonated fraction of bulk rock samples together with clinoptilolite (Supplementary information). Thus authigenic clay minerals and zeolites may contribute significantly to the REE pattern and $\mathrm{Nd}$ isotope composition of the residues analysed in this study. These authigenic minerals form at the sediment-water interface, in contact with bottom waters, and may partly integrate the signature of bottom waters or that of surrounding oxides by exchange processes in the sediment (Chamley and Bonnot-Courtois, 1981; Dubinin, 2004). As a result, we here consider that, independently of the origin of the MREE-enriched REE patterns recorded in the residue fraction, which can arise from remaining oxides or authigenic minerals, the carbonate/oxidefree residual fractions have likely recorded a mixed $\mathrm{Nd}$ isotope signal between a purely detrital composition and a bottom water composition.

For Site 690 , our Late Cretaceous $\varepsilon_{\mathrm{Nd}(\mathrm{t})}$ data of fish remains and foraminiferal $\mathrm{HH}-$ extraction plot within the range defined by recently published deep-water $\mathrm{Nd}$ isotope data (Voigt et al., 2013; Murphy and Thomas, 2013) with the exception of two samples yielding a more negative $\mathrm{Nd}$ isotope composition, below -11 $\varepsilon$-units (-11.6 and -11.2) (Fig. 5-A). This discrepancy may be analytical, as these two samples present a slightly higher analytical uncertainty on $\varepsilon_{\mathrm{Nd}}(2 \sigma=0.4)$, and the second measurement for sample $690-24$ yielded a higher $\varepsilon_{\mathrm{Nd}(\mathrm{t})}$ value of $10.5 \varepsilon$-units that is within the range defined by previously published data. It is unlikely that these negative values arise from a detrital contamination in the foraminifera tests, as the published $\mathrm{Nd}$ isotope composition of detrital material for this site have higher $\varepsilon_{\mathrm{Nd}(\mathrm{t})}$ values between -11.2 and -10 $\varepsilon$-units (Murphy and Thomas, 2013; Voigt et 
al., 2013). Our residual values for this site tend to yield slightly higher $\varepsilon_{\mathrm{Nd}(\mathrm{t})}$ values than those previously published and in the range defined by deep-water $\varepsilon_{\mathrm{Nd}(\mathrm{t})}$ values. As specified above, the residual fraction that we analysed here, using a slightly different procedure to that of Murphy and Thomas (2013) and Voigt et al. (2013), hosts neo-formed clay and other authigenic minerals possibly impervious to our leaching procedures, and the residue samples measured in this work are likely to have recorded a mixed purely detrital/deep-water signal at Site 690.

\subsection{Deep-water communications between and within the South Atlantic and Indian} oceans prior to the Campanian

Over recent years, an increasing number of paleoceanographic investigations using $\mathrm{Nd}$ isotopes have led to significant improvement of the spatial and temporal coverage of $\varepsilon_{\mathrm{Nd}(\mathrm{t})}$ data for the Late Cretaceous (e.g. MacLeod et al., 2008; Robinson et al., 2010; Robinson and Vance, 2012; Martin et al., 2012; Murphy and Thomas; 2012; 2013; Voigt et al., 2013). Different scenarios for the past deep-water circulation patterns have been suggested based on these data sets, being constantly refined in order to integrate the latest data from additional deep-sea sites.

During the early Late Cretaceous, multiple sources of deep-waters have been recently suggested for the South Atlantic and the proto-Indian oceans (Murphy and Thomas, 2012; 2013). This interpretation is based on differences in $\mathrm{Nd}$ isotope values (about $1 \varepsilon$-unit between each site) and trends observed between sites 511 (Falkland Plateau), 530 (Angola Basin), and 361 (Cape Basin; Fig. 6-B). Neodymium isotope values at Site 361 are quite similar from the Turonian to the late Coniacian to those at Site 1138 (western side of the Kerguelen plateau), which has been interpreted to reflect a common water mass bathing these two sites (Fig. 6-B; Murphy and Thomas, 2013). By contrast, different values and trends recorded between Site 
1138 and sites 763,765 , and 766 on the western margin of Australia have been suggest to reflect different water masses on both sides of the Kerguelen Plateau. Prior to $80 \mathrm{Ma}$, this plateau may have impeded deep-water communications between the Indian sector east of the Kerguelen Plateau and the southern Atlantic (Murphy and Thomas, 2012). Similarly, the Rio Grande Rise-Walvis Ridge complex in the south Atlantic may have precluded communications between the northern part of the South Atlantic, bathing Site 530, and the southern Atlantic ocean where different values are recorded at sites 511 and 361 (Robinson et al., 2010; Murphy and Thomas, 2013).

Our new bottom water $\varepsilon_{\mathrm{Nd}(\mathrm{t})}$ values from sites 258 and 700 lie well within the range and trend defined by the data already published for the Indian sector and southern Atlantic during the Late Cretaceous (Fig. 6-B). In the Turonian-Santonian interval, the relatively radiogenic values at deep-sea Site 258 ( -8.5 to -6.5 $\varepsilon$-units) are very similar to those inferred for sites 1135, 1138, 763 and 765 also situated in the proto-Indian Ocean, although at the lower end of the slightly more radiogenic values of Site 766 located at equivalent paleodepth. The $\varepsilon_{\mathrm{Nd}(\mathrm{t})}$ values of sites 258,763 , and 765 east of the Kerguelen Plateau and the values of sites 1135 and 1138 west (or on) the Kerguelen Plateau actually appear to be quite similar from $\sim 93$ to $\sim 87$ Ma (Fig. 6-B).

This feature is not incompatible with the existence of multiples local water masses generated in different locations and filling separated austral basins (Murphy and Thomas, 2013). Nevertheless, an alternative interpretation would be the existence of a common water mass extending from intermediate to abyssal depth in these regions as early as the Turonian. The formation of the southern portion of Kerguelen Plateau occurred during the Albian (from -115 to -101 Ma). It remained aerially exposed from -11 to $20 \mathrm{Ma}$ before drowning due to thermal subsidence (Coffin, 1992; Whitechurch et al., 1992), hence a large part of the southern portion was already below sea level by the Turonian, albeit not very deep. At 
present, a substantial gap, namely the Princess Elizabeth Trough, can be observed between eastern Antarctica and the southern portion of the Kerguelen Plateau. This trough reaches depths lower than 2000 m with respect to the shallower portions of the Southern Kerguelen Plateau. Therefore, intermediate to deep-water masses from the Atlantic sector may have reached the Indian sector before the Campanian through this southern trough if it was already deep enough at that time, as suggested by paleogeographic reconstructions (Sewall et al., 2007; Ali and Aitchison, 2009).

Interestingly, prior to the Campanian, intermediate water $\varepsilon_{\mathrm{Nd}(\mathrm{t})}$ values recorded from Site 700, closer to the Rio Grande Rise-Walvis Ridge complex than sites 361 and 511, are indistinguishable from the deep-water $\varepsilon_{\mathrm{Nd}(\mathrm{t})}$ values recorded at Site 530 located north of the complex, with the exception of an interval presenting highly radiogenic values (Fig. 6-B). This interval, from the late Santonian to the mid-Campanian, is marked by an increase of volcanogenic sediments at this site, and most likely records the impact of preferential alteration of volcanic glass particles on local deep-waters or on pore waters during this limited time-period (data in the dotted dark blue frame on Fig. 6-B; Robinson et al., 2010; Murphy and Thomas, 2013). The similarity between the $\varepsilon_{\mathrm{Nd}(\mathrm{t})}$ values of sites 530 and 700, apart from the highly radiogenic and probably local excursion at Site 530, hints again at the existence of a common water mass bathing these sites prior to the Campanian.

This interpretation would, however, require the existence of a breach in the Rio Grande Rise-Walvis Ridge complex prior to the Campanian. At present, the Rio Grande Rise and the Walvis Ridge form two complexes of isolated volcanic seamounts, associated with the Gaugh and Tristan Hot Spots. They correspond to diachronous pulses of volcanism, occurring at different periods which can be identified by radiometric ages (Fig. 7). The formation of the complexes began in the earliest Cretaceous ( 133 Ma; Renne et al. 1992; Stewart et al., 1996; Fig. 7) with the Paraná volcanic traps in South America and their smaller counterparts, the 
Etendeka traps, in Namibia and Angola. Bathymetry in the South Atlantic apart from these volcanic complexes was already important during the Turonian, as the tilting of the Brazilian and Angolan margins was complete by the end of the Albian when the bathymetry of the South Atlantic had reached 4000 meters. This is indicated by thin-skinned spectacular gravitational extension of the post-rift succession over the underlying Aptian evaporates in the Angolan coastal basins (Kwanza and Benguela Basins) north of the Rio Grande Rise-Walvis Ridge complex, which reflects the tilting of the young continental margin by differential thermal subsidence (Jackson and Hudec, 2005; Guiraud et al., 2010).

Based on the radiometric ages of the different volcanic units composing the Walvis Ridge-Rio Grande Rise complex (Fig. 7; Renne et al., 1992; Stewart et al., 1996; O’Connor and Duncan 1990; Rohde et al., 2013), only the pre-Turonian volcanic seamounts were present during the Turonian (red elements on Fig. 7 and Fig. 8: São Paulo Rise and western Rio Grande Rise on the west, early Cretaceous proto-Walvis Ridge on the east), which left an open breach between the proto-Rio Grande Rise and the Walvis Ridge (Fig. 8). In addition, the volcanic highs prevailing at the São Paulo Plateau and at the eastern Walvis Ridge were only a few hundred meters to 1000 meters above the oceanic floor (see detailed bathymetry on Fig. 8; O’Connor and Duncan, 1990).

All these observations strongly suggest that as early as the Turonian, the Rio Grande Rise-Walvis Ridge complex did not act as a continuous high barrier, but most likely allowed confined deep marine communications between the central (B) and south (C) segments of the South Atlantic ocean. After the Turonian, existing radiometric ages for the eastern Rio Grande Rise and the northern Walvis Ridge (87-80 Ma and 79-54 Ma, respectively; green elements on Fig. 7) indicate that consecutive volcanic pulses had generated seamounts within the Santonian to Maastrichtian interval. It is interesting to note that the two radiogenic excursions recorded at sites 530 and 525 occur within these two intervals, 97-80 Ma and 79- 
$54 \mathrm{Ma}$, respectively. Although these seamounts may have complicated deep-water communication after the Coniacian in the South Atlantic, they remained discontinuous and not high above the oceanic floor apart from very limited areas (Fig. 7 and Fig. 8; Barker, 1983; O’Connor and Duncan, 1990; Rohde et al., 2012). As a result, we argue here that from the Turonian onward, the Rio Grande Rise-Walvis Ridge complex probably did not constitute a barrier for deep-water exchanges, even though the path of the water masses may have been complicated by the discontinuous volcanic seamounts generated. If confirmed, then the similarity in the $\varepsilon_{\mathrm{Nd}(\mathrm{t})}$ values and trends of sites 530 and 700 could be interpreted as resulting from the existence of a common deep-water mass bathing these two sites.

Our work thus supports the possible existence of a common deep-water mass bathing southern Atlantic and Indian sites as early as the Turonian, which could have extended to the west of Site 700, to the north of Site 530, and to the east of Site 765. It should be noted that the existence of a common water mass as early as the mid-Cretaceous within the entire South Atlantic and Indian oceans does not preclude the occurrence of differences in $\varepsilon_{\mathrm{Nd}(\mathrm{t})}$ values between sites, which may arise from local particle-seawater exchanges. Such differences have been noted already between sites 763,765 , and 766 that are geographically very close to each other although at different paleodepths (Fig. 6-B). These discrepancies have been interpreted in terms of proximity to local weathering inputs, resulting in a different local imprint on a common water mass which could have bathed these sites (Murphy and Thomas, 2012). Local inputs of detrital or volcanogenic particles may have similarly partially imprinted the original composition of the deep-water mass arriving at the different South Atlantic and Indian sites, explaining the differences of signature between the sites across the southern basins.

\subsection{Evolution of the Nd isotope composition of the Southern Ocean and North Atlantic} during the Campanian-Maastrichtian interval 
A major feature of the existing Late Cretaceous deep and intermediate $\varepsilon_{\mathrm{Nd}}$ data is the decrease recorded during the Campanian in the North and South Atlantic, as well as in the Indian Ocean. This was first highlighted by Robinson et al. (2010) and since confirmed by additional records (Fig. 6). Our data from Site 700 follow this decrease of $\sim 2 \varepsilon$-units with more unradiogenic values recorded during the Maastrichtian than during the Coniacian to Santonian interval (Fig. 6-B). In order to get a better view of the trends in deep-water $\varepsilon_{\mathrm{Nd}(\mathrm{t})}$ in the different regions of the oceans during the Late Cretaceous, statistics have been performed on a compilation of existing $\mathrm{Nd}$ isotope data, described in the Supplementary information (Table S1). Results of the statistical treatment applied to the data, presented in Figure 6, confirm the existence of a significant decrease in the $\mathrm{Nd}$ isotope composition of deep-waters in the North Atlantic, South Atlantic and Indian oceans, as recognised by several authors over the last few years (Robinson et al., 2010; Martin et al., 2012; Murphy and Thomas, 2012; 2013).

Following our preferred interpretation of a common water mass bathing the South Atlantic and Indian oceans, the decreasing trend recorded in the North Atlantic, South Atlantic and Indian sites could be due to (i) the initiation of deep-water production in the northern Atlantic, which could have progressively reached the southern Atlantic with the deepening of the Central Atlantic Gateway during the Late Cretaceous (the 'Northern Component Water' or NCW; MacLeod et al., 2011; Martin et al., 2012; Fig. 1), or (ii) a modification of the $\mathrm{Nd}$ isotope composition of a deep-water mass sourced in the Atlantic or Indian sector of the Southern Ocean (the 'Southern Component Water' or SWC; Murphy and Thomas, 2012; 2013; Fig. 1). Our new $\varepsilon_{\mathrm{Nd}(\mathrm{t})}$ values at Site 690 for the late CampanianMaastrichtian interval are similar to those from previous studies (Murphy and Thomas, 2013; Voigt et al., 2013) and resemble the values from the South Atlantic and the Austral Ocean ( 11 to -8), thus supporting the idea that the high latitudes near the region of Maud Rise could 
have been a source area for the deep-waters of the SCW during this period. As proposed by Murphy and Thomas (2013), a decrease of the southern Atlantic surface waters $\varepsilon_{\mathrm{Nd}(\mathrm{t})}$ values during the Late Cretaceous could have been due to the restriction of Pacific radiogenic surface water inputs through a shallower Drake Passage and to the subsidence of existing LIPs, like parts of the Kerguelen Plateau. Once below sea level, these LIPs would have ended their contribution of weathered $\mathrm{Nd}$ to the surface waters in the southern Atlantic and Indian oceans.

Interestingly, the central Atlantic sites on the Demerara Rise (1258-1261) and Cape Verde (367) display Nd isotope values markedly lower than at any other sites from the North or South Atlantic (Fig. 6-A). Some studies have suggested that the low values ( -17 to -12 $\varepsilon-$ values) recorded at Demerara Rise could reflect the existence of a deep- or intermediate water mass produced nearby, the Demerara Bottom Water (DBW), for most of the Late Cretaceous (MacLeod et al., 2011; Martin et al., 2012). Following this interpretation, it has been suggested that the decrease of $\varepsilon_{\mathrm{Nd}(t)}$ values recorded at Cape Verde could have reflected the propagation of the DBM eastward to the African coast (MacLeod et al., 2011). Yet this peculiar signature is not recorded at other North Atlantic sites, which would tend to indicate that the DBM would have a quite limited spatial extension. In addition, even though the $\mathrm{Nd}$ isotope record at Cape Verde presents an offset toward lower values compared to other North Atlantic sites, the decreasing trend in $\varepsilon_{\mathrm{Nd}(\mathrm{t})}$ values mirrors those of the other sites (Fig. 6-A). An alternative interpretation could again involve the local impact of boundary exchanges (Lacan and Jeandel, 2005a). Such seawater-particle exchange would have lowered the $\varepsilon_{\mathrm{Nd}}$ composition of any deep-water mass bathing these sites, either from the North or from the South Atlantic, given the proximity of the Western African Craton. This hypothesis could explain both the offset and the similar decreasing trend recorded at Cape Verde. 


\subsection{Implications for the circulation in the Caribbean region during the Maastrichtian}

\section{and Paleocene}

During the Cenomanian-Turonian interval, sites 386 and 1050 in the western part of the North Atlantic are characterised by quite radiogenic $\varepsilon_{\mathrm{Nd}(\mathrm{t})}$ values ( - 7 to $-5 \varepsilon$-units) compared to sites 367 and 551, respectively on the southern and eastern part of the basin ( -9; Fig. 6-A; Martin et al., 2012), which could indicate an inflow of radiogenic Pacific deepwaters through the Caribbean Seaway. By contrast, during the Campanian-Maastrichtian interval, sites 386 and 1050 present lower values reaching those of the rest of the North Atlantic ( -10 to -8). This evolution could reflect a decreasing inflow of radiogenic water from the Pacific due to the restriction of the Caribbean Seaway, related to the initiation of a second subduction zone during the Campanian, as well as the onset of deep-water production with a low $\varepsilon_{\mathrm{Nd}}$ signature in the North Atlantic (Martin et al., 2012; Robinson and Vance, 2012; Voigt et al., 2013).

Considerations concerning potential connections between the Atlantic and Pacific basins during the Cretaceous are complicated by the still poorly constrained paleogeography of this region. As the Caribbean Plate migrated eastward between North and South America, a subduction zone initiated during the Aptian and formed the Caribbean Arc. The Caribbean Plate was then disconnected from the Farallon Plate by another subduction zone initiated during the Campanian, creating the Panama-Costa Rica Arc (Pindell and Kennan, 2009; Buchs et al., 2010). Thus the Caribbean Plate was delimited on its eastern and western boundaries by two volcanic arcs. Nevertheless, paleogeographic reconstructions for the period suggest that the Caribbean Seaway was opened for deep-water exchanges during the Maastrichtian, albeit with discontinuous volcanic islands complicating the pathway of the water masses, similarly to modern Indonesia (Sewall et al., 2007; Fig. 1). 
Our results from Site 152 are the first $\varepsilon_{\mathrm{Nd}(\mathrm{t})}$ data generated for a site situated in the Caribbean Seaway for the Maastrichtian and the Paleocene. They reveal quite radiogenic values for the intermediate waters in this region ( -6 to $-3 \varepsilon$-units), markedly higher than other North Atlantic sites (Fig. 6-A). Interestingly, our residue samples at Site 152 systematically present even more radiogenic $\varepsilon_{\mathrm{Nd}(\mathrm{t})}$ values than the coeval fish teeth or $\mathrm{HH}$ extraction of foraminifera samples ( $\sim 1$ to $2 \varepsilon$-units higher), which bear the signature of the local bottom water. As discussed above (see section 5.1), the signature of the residue likely represents a mix between a local seawater signal (recorded by authigenic mineral phases) and a detrital signal (recorded by preformed minerals brought by continental erosion). Yet a seawater signal less radiogenic than the residue signal implies that the purely detrital fraction must be even more radiogenic than the residue. This feature is consistent with the common occurrence of volcanogenic sediments and volcanic ash at Site 152, attesting subaerial volcanism in this area during the Maastrichtian and Paleocene (Edgar et al., 1973). Thus, a water mass flowing into the region of Site 152 would be expected to become more radiogenic through seawater-particle interactions, in the same way as the intermediate and deep-waters in the modern North Pacific, or the bottom waters in the modern Caribbean region (Horikawa et al., 2011; Osborne et al., 2014). Hence, as local seafloor waters at Site 152 are less radiogenic than the residue fraction, they must come from a region characterised by less radiogenic waters. Based upon the compilation of the $\varepsilon_{\mathrm{Nd}(\mathrm{t})}$ values available for the Late Cretaceous in the Pacific ( -5 to -3 $\varepsilon$-units) and the North Atlantic ( -10 to -8), we propose that intermediate waters were flowing from the Atlantic to the Pacific through the Caribbean Seaway during the Maastrichtian and the Paleocene (Fig. 6-A). This circulation toward the west would have prevented incursion of radiogenic Pacific seawater, explaining the lower $\varepsilon_{\mathrm{Nd}(\mathrm{t})}$ values observed in the North Atlantic during the Maastrichtian. 


\subsection{Insights for the circulation in the Pacific}

Large uncertainties remain concerning the origins of the deep-water masses bathing the Pacific during the Late Cretaceous. The North Pacific area has been proposed as a potential area for deep-water production during the Cretaceous (Otto-Bliesner et al., 2002; Thomas, 2004; Frank et al., 2005; Hague et al., 2012). This zone is at present surrounded by very radiogenic terranes (in the -0.5 to +10 -units range; Zhuravlev et al., 1987; Nakai et al., 1993; Jeandel et al., 2007) emplaced through island arc volcanism. Subduction in the North Pacific was already active during the Late Cretaceous (Larson and Pitman, 1972), and very radiogenic upper ocean waters ( -3 to -1; Moiroud et al., 2013) have been reported on the northern and northwestern margins of the North Pacific during this period. In the case of upper ocean waters sinking to depth, the radiogenic signature could then be exported to the central Pacific, and possibly the southern Pacific. Deep-water may also have been produced in the southern Pacific high latitudes (Brady et al., 1998; DeConto et al., 2000; Hague et al., 2012; Thomas et al., 2014). At present, the Nd isotope composition of sediments eroded from West Antarctica (including the Antarctic Peninsula and the regions west to the Antarctic peninsula), typically falls in the range of +1 to $-6.5 \varepsilon$-units (van de Flierdt et al., 2007; Roy et al., 2007; Jeandel et al., 2007; Carter et al;, 2012), reflecting the presence of abundant late Mesozoic-Cenozoic intrusive and volcanic rocks arranged around Paleozoic and Mesozoic arc-related blocks (Dalziel and Elliot, 1982; Dalziel, 1992; Vaughan and Storey, 2000). During the Late Cretaceous, abundant volcanism associated with the development of the Pacific margin on West Antarctica was thus active, and intrusive and volcanic rocks most likely were already providing radiogenic material to the nearby surface waters at that time, albeit less radiogenic than on the northern Pacific margin. Further to the west, the sediments eroded from the region located in the vicinity of the modern Ross Sea are characterised by Nd isotope values typically of -7.3 to $-2.7 \varepsilon$-units (Roy et al., 2007; Jeandel et al., 2007), but they 
can also reach values as low as -20.8 $\varepsilon$-units (Hergt et al., 1989). These values reflect the mixing of old Antarctic basement terrains and magmatic material exposed on both sides of the embayment, including the radiogenic material from West Antarctica, and the presence of Jurassic flood basalts in the Transantarctic Mountains (Fleming et al., 1995; Roy et al. 2007). Thus deep-water produced in the southern Pacific can be expected to have lower values than those recorded in the northern Pacific, although still quite radiogenic.

Thomas et al. (2014) reported during the Maastrichtian differences between the quite radiogenic bottom water $\varepsilon_{\mathrm{Nd}(\mathrm{t})}$ values at Site 323 ( -4 to -3 $\varepsilon$-units), located during this period at a paleodepth of $\sim 2000 \mathrm{~m}$, and deep-water $\varepsilon_{\mathrm{Nd}(\mathrm{t})}$ values at Site 596 ( -6 to -5.5 $\varepsilon$-units), located in the South Pacific at lower latitudes and at a greater paleodepth of $\sim 5000 \mathrm{~m}$. The more radiogenic values recorded at Site 323 during the Maastrichtian resemble those of the central and north Pacific (Thomas, 2004; Frank et al., 2005; MacLeod et al., 2008; Le Houëdec et al., 2009; Hague et al., 2012; Fig. 6-C). Based on the similarities of $\varepsilon_{\mathrm{Nd}(t)}$ values at Site 323 with those of the North Pacific sites and on their difference with those at Site 596, the authors have suggested (i) an influence of intermediate to deep-water masses from the North Pacific southward up to $60^{\circ} \mathrm{S}$ and at a depth up to $2000 \mathrm{~m}$, and (ii) that the source region of the deep-waters bathing Site 596 was not located in the region of Site 323 (West Antarctica) during the Maastrichtian but elsewhere in the southern Pacific.

Our new data from Site 323, although limited, basically only confirm both the range of values and the decrease from $\sim-3 \varepsilon$-units in the Maastrichtian to -5.5 $\varepsilon$-units in the Danian highlighted by published values at this site (Thomas et al., 2014: Fig. 5-B). This decrease has been interpreted by Thomas et al. (2014) as arising from the deepening of Site 323, from paleodepths of $\sim 2000 \mathrm{~m}$ in the Maastrichtian to paleodepths of $\sim 3000 \mathrm{~m}$ in the Danian, when it would reach the deeper water mass bathing Site 596. As argued by these authors, and supported by their simulations of ocean circulation, this deep-water mass bathing the South 
Pacific is likely to have originated from the Pacific sector of the Southern Ocean, considering its lower $\varepsilon_{\mathrm{Nd}(\mathrm{t})}$ values ( - 6 to $-5 \varepsilon$-units) compared to contemporaneous $\mathrm{Nd}$ isotope values from sites located in the tropical and North Pacific, which lie more in the -3.5 to $-5.5 \varepsilon$-units range.

Interestingly, the statistical treatment applied to the compilation of intermediate and deep-water $\mathrm{Nd}$ isotope data presented in Figure 6-C highlights a trend toward more radiogenic values recorded by the central Pacific sites from the Maastrichtian to the end of the Paleocene. This trend, previously identified at Shatsky Rise in the central Pacific (Thomas, 2004), had been originally interpreted as reflecting the replacement in the equatorial Pacific of a deepwater mass sourced in the South Pacific in the Maastrichtian by a deep-water mass sourced in the North Pacific in the late Paleocene and Eocene. Our compilation and statistical treatment indicate that this increasing trend appears more pronounced in the tropical North Pacific (dark red symbols and frames on Fig. 6-C) with an increase of $\sim 4 \varepsilon$-units, compared to the equator (medium red symbols and frames on Fig. 6-C) where the recorded increase is $\sim 1 \varepsilon$-unit, and tropical South Pacific (light red symbols and frames on Fig. 6-C) with an increase of $\sim 0.8 \varepsilon$ units. This evolution was not restricted to the Pacific but seems to be also recorded in the South Atlantic ( 1.5 $\varepsilon$-units increase, dark blue symbols and frames on Fig. 6-C; and $\sim 1 \varepsilon-$ units increase at Site 690, dark orange symbols and frames on Fig. 6-C) and Indian oceans ( 2 $\varepsilon$-units increase, orange symbols and frames on Fig. 6-C). The northeast sector of the North Atlantic also appears to record an increase in bottom water $\varepsilon_{\mathrm{Nd}}$ values with values $\sim 2.5 \varepsilon$-units more radiogenic in the Eocene compared to the Maastrichtian.

The origin of this increase depicted in the different oceans still remains unclear, especially as exceptions are depicted at Site 596 in the South Pacific (and at Site 323 where a decreasing trend is recorded but has been linked to an increase of depth) and at Site 1050 in the northwest sector of the North Atlantic. The record of this increase in several oceanic 
basins may hint of a potential influence of increased radiogenic inputs in one of the areas of deep-water production. A concomitant decrease in seawater ${ }^{87} \mathrm{Sr} /{ }^{86} \mathrm{Sr}$ values from the Maastrichtian to the Early Eocene points to an increased contribution of a mantellic source of strontium to seawater, possibly through weathering of subaerially exposed magmatic material (Hodell et al., 2007). The most pronounced increase in deep-water Nd isotope composition is recorded in the North Pacific, suggesting that this region could have been closer to the source area. During the latest Cretaceous and early Cenozoic, the northern Pacific margins were affected by the accretion of numerous terranes and the formation of volcanic arcs, with the subduction of the Izanagi-Pacific Ridge beneath southern Japan (Dumitru et al., 1995; Mackey et al., 1997; Harbert et al., 2001; Seton et al., 2015). Such events could have caused increasing subaerial exposure of volcanogenic material in the Bering region, leading to more radiogenic surface water in the northern Pacific. If deep-water continuously formed in this area, the increasingly radiogenic signature delivered to the nearby surface waters could then have propagated in the ocean basin through exchange with other water masses and eventually have affected to some extent deep-waters in the Atlantic and Indian oceans. In this scenario, one feature that remains unclear concerns the stability of the $\mathrm{Nd}$ isotope signal recorded at Site 596 (Thomas et al., 2014). $\varepsilon_{\mathrm{Nd}(\mathrm{t})}$ values would be expected to increase to some extent from the Maastrichtian to the Eocene as the site is closer to the source region than Atlantic and Indian sites. The absence of variation in $\varepsilon_{\mathrm{Nd}(\mathrm{t})}$ values at this site may indicate that North Pacific deep-waters did not penetrate far into the South Pacific, or may indicate limited mixing with the shallower North Pacific deep-waters, as Site 596 is located at greater depths (5000 m) than the other Pacific sites.

\section{Conclusions}


We have measured the $\varepsilon_{\mathrm{Nd}}$ signature of fish remains, $\mathrm{HH}$-extraction of foraminifera and residual fraction from new DSDP/ODP sites as well as from sites already partly investigated for Nd isotopes in the Southern Ocean, the Caribbean Seaway and the South Pacific. Surprisingly, $\varepsilon_{\mathrm{Nd}}$ values of the residual fraction follow the same evolution as bottom water values at sites 152 and 690 where residues have been analysed, although with numbers offset toward more radiogenic values. XRD analyses reveal the abundant presence of authigenic minerals like clinoptilolite at both sites, which may explain the enrichment in MREE recorded on the spectra of the residual fractions, instead of a flat rare earth element spectra typical of detrital clays. The presence of these authigenic minerals, which are likely to carry a seawater $\mathrm{Nd}$ isotope signature, may explain the similar evolution of the residual fraction and bottom water $\varepsilon_{\mathrm{Nd}}$ values.

During the Turonian-Santonian interval, the similarity of deep-water $\varepsilon_{\mathrm{Nd}}$ values between sites 700 and 530 on both sides of the Walvis Ridge-Rio Grande Rise Complex, and between Site 258 and sites 1138 and 1135 on both sides of the Kerguelen Plateau, along with tectonic considerations, argue for the existence of possible deep-water communications through these barriers prior to the Campanian. Based on our new $\varepsilon_{\mathrm{Nd}(\mathrm{t})}$ values from sites 258, 700 and 690, together with published literature data, we propose that a common water mass could have bathed the South Atlantic and Indian oceans at least as early as the Turonian, with the most likely source of this water mass probably located in the high latitudes of the Atlantic sector of the Southern Ocean. The differences in $\varepsilon_{\mathrm{Nd}(\mathrm{t})}$ values which still exist between some austral sites could then reflect modifications of the source signal though local particleseawater exchanges rather than multiple sources of intermediate or deep-water masses.

Our new results also document a common decrease of seawater $\varepsilon_{\mathrm{Nd}(\mathrm{t})}$ values affecting the entire Atlantic and Southern oceans during the Campanian. This feature could either stem from the reduction of inflow of Pacific waters through the Drake Passage or the subsidence of 
the LIPs, exporting less radiogenic material to the ambient seawater. The new data from Site 152 document a possible westward circulation of Atlantic intermediate water into the Pacific through the Caribbean Seaway during the Maastrichtian and Paleocene. Together with the restriction of the Drake Passage, the reduction of inflow of Pacific waters and the drowning of volcanic ridge and plateaus may have also accounted for the decreasing $\varepsilon_{\mathrm{Nd}(\mathrm{t})}$ values in the Atlantic and the Southern Ocean during the Campanian-Maastrichtian interval.

The few data from Site 323 basically confirm the already published range of data and trends at this site. When compared to other Pacific sites during the Maastrichtian and the Paleocene interval, these data suggest that two distinct deep-water masses occurred in the North and South Pacific by the end of the Cretaceous.

Additionally, we document a common increasing trend in almost all the oceanic basins from the Late Maastrichtian to the early Eocene. The North Pacific presents the most important rise of $\varepsilon_{\mathrm{Nd}(\mathrm{t})}$ values compared to the other basins. If production of deep-water occurred in this area, this evolution could imply a major shift in the radiogenic inputs into the North Pacific during the Early Cenozoic warming, which would have carried this more radiogenic signature into the other oceanic basins.

\section{Acknowledgments}

The author thanks the Integrated Ocean Drilling Program for supplying sample material. This work was supported by funding from the INSU program SYSTER and the ANR project Anox-Sea. C. Bassoulet, E. Ponzevera and Y. Germain are thanked for their help during trace element and isotopic analyses. We are also very grateful for the constructive comments from A. Piotrowski and from an anonymous reviewer that greatly helped to improve the paper. 


\section{References}

Ali, J.R., and J.C. Aitchison (2009), Kerguelen Plateau and the Late Cretaceous southerncontinent bioconnection hypothesis: tales from a topographical ocean. J. Biogeogr. 36 (9), 1778-1784, doi:10.1111/j.1365-2699.2009.02105.x.

Amakawa, H., D.S. Alibo, and Y. Nozaki (2004), Nd abundance and isotopic composition distributions of surface seawaters of the Northwest Pacific Ocean and its adjacent seas. Geochem. J. 38 (6), 493-504.

Amakawa, H., K. Sasaki, and M. Ebihara (2009), Nd isotopic composition in the central North Pacific. Geochim. Cosmochim. Acta 73 (16), 4705-4719, doi:10.1016/j.gca.2009.05.058.

Arsouze, T., J.-C. Dutay, F. Lacan, and C. Jeandel (2009), Reconstructing the Nd oceanic cycle using a coupled dynamical - biogeochemical model. Biogeosciences 6, 28292846, doi:10.5194/bg-6-2829-2009.

Arraes-Mescoff, R., M. Roy-Barman, L. Coppola, M. Souhaut, K. Tachikawa, C. Jeandel, R. Sempéré, and C. Yoro (2001), The behavior of Al, Mn, Ba, Sr, REE, and Th isotopes during in vitro degradation of large marine particles. Mar. Chem. 73 (1), 1-19, doi:10.1016/S0304-4203(00)00065-7.

Axelsson, M.D., I. Rodushkin, J. Ingri, and B. Ohlander (2002), Multielemental analysis of Mn-Fe nodules by ICP-MS: optimisation of analytical method. Analyst 127 (1), 7682, doi:10.1039/B105706P.

Barker, P.F. (1983), Tectonic evolution and subsidence history of the Rio Grande Rise. In: P.F. Barker, R.L. Carlson, and D.A. Johnson (Eds.), Initial Rep. Deep Sea Drill. Proj. 72, Washington (U.S. Gov. Print. Off.), 953-976. 
Barker, P.R, J.P. Kennett, et al. (1988), Shipboard Scientific Party, site 690. In: Proc. Ocean Drill. Program Initial Rep. 113, College Station, TX (Ocean Drilling Program), 183292.

Barrat, J.A., F. Keller, J. Amossé, R.N. Taylor, R.W. Nesbitt, and T. Hirata, (1996), Determination of rare earth element in sixteen silicate reference samples by ICP-MS after Tm addition and ion exchange separation. Geostand. Newslett. 20 (1), 133-139, doi:10.1111/j.1751-908X.1996.tb00177.x.

Barrera, E., S.M. Savin, E. Thomas, and C.E. Jones (1997), Evidence for thermohalinecirculation reversals controlled by sea-level change in the latest Cretaceous. Geology 25 (8), 715-718, doi:10.1130/0091-7613(1997)025<0715:EFTCRC>2.3.CO;2.

Barron, E.J., P.J. Fawcett, W.H. Peterson, D. Pollard, and S.L. Thompson (1995), A simulation of mid-Cretaceous climate. Paleoceanography 10 (5), 953-962, doi:10.1029/95PA01624.

Bayon, G., C.R. German, R.M. Boella, J.A. Miltont, R.N. Taylor, and R.W. Nesbitt (2002), An improved method for extracting marine sediment fractions and its application to $\mathrm{Sr}$ and Nd isotopic analysis. Chem. Geol. 187 (3-4), 179-199, doi:10.1016/S00092541(01)00416-8.

Bayon, G., C.R. German, K.W. Burton, R.W. Nesbitt, and N. Rogers (2004), Sedimentary $\mathrm{Fe}-\mathrm{Mn}$ oxyhydroxides as paleoceanographic archives and the role of aeolian flux in regulating oceanic dissolved REE. Earth Plan. Sci. Lett. 224 (3-4), 477-495, doi:10.1016/j.eps1.2004.05.033.

Bayon, G., J.-A. Barrat, J. Etoubleau, M. Benoit, S. Révillon, and C. Bollinger (2009), Determination of rare earth elements, Sc, Y, Zr, Ba, Hf and Th in geological samples by ICP-MS after Tm addition and alkaline fusion. Geostand. Geoanal. Res. 33 (1), 51-62, doi:10.1111/j.1751-908X.2008.00880.x. 
Bouvier, A., J.D. Vervoort, and P.J. Patchett (2008), The Lu-Hf and Sm-Nd isotopic composition of CHUR: Constraints from unequilibrated chondrites and implications for the bulk composition of terrestrial planets. Earth Plan. Sci. Lett. 273 (1-2), 48-57, doi:10.1016/j.eps1.2008.06.010.

Brady, E.C., R.M. DeConto, and S.L. Thompson (1998), Deep water formation and poleward ocean heat transport in the warm climate extreme of the Cretaceous (80 Ma). Geophys. Res. Lett. 25 (22), 4205-4208, doi:10.1029/1998GL900072.

Buchs, D.M., R.J. Arculus, P.O. Baumgartner, C. Baumgartner-Mora, and A. Ulianov (2010), Late Cretaceous arc development on the SW margin of the Caribbean Plate: Insights from the Golfito, Costa Rica, and Azuero, Panama, complexes. Geochem. Geophys. Geosyst. 11 (7), Q07S24, doi:10.1029/2009GC002901.

Carter, P., D. Vance, C.D. Hillenbrand, J.A. Smith, and D.R. Shoosmith (2012), The neodymium isotopic composition of waters masses in the eastern Pacific sector of the Southern Ocean. Geochim. Cosmochim. Acta 79, 41-59, doi:10.1016/j.gca.2011.11.034.

Chamley, H., and C. Bonnot-Courtois (1981), Argiles authigènes et terrigènes de l'Atlantique et du Pacifique NW (Leg 11 et 58 DSDP) : apport des terres rares. Oceanol. Acta 4 (2), 229-238.

Charbonnier, G., E. Pucéat, G. Bayon, D. Desmares, G. Dera, C. Durlet, J.-F. Deconinck, F. Amédro, A.T. Gourlan, P. Pellenard, and B. Bomou (2012), Reconstruction of the Nd isotope composition of seawater on continental margin: testing the potential of Fe-Mg oxyhydroxide coatings on foraminifera tests. Geochim. Cosmochim. Acta 99, 39-56, doi:10.1016/j.gca.2012.09.012. 
Ciesielski, P. F., Y. Kristoffersen, et al. (1988), Shipboard Scientific Party, site 700. In: Proc. Ocean Drill. Program Initial Rep. 114, College Station, TX (Ocean Drilling Program), 255-361.

Coffin, M.F. (1992), Emplacement and subsidence of Indian Ocean plateaus and submarine ridges. In: R. A. Duncan (Ed.), Synthesis of Results from Scientific Drilling in the Indian Ocean, Geophys. Monogr. Ser. 70, AGU, Washington, D. C., 115-125, doi:10.1029/GM070p0115.

Craggs, H.J., P.J. Valdes, and M. Widdowson (2012), Climate model predictions for the latest Cretaceous: An evaluation using climatically sensitive sediments as proxy indicators. Palaeogeogr. Palaeoclimatol. Palaeoecol. 315-316, 12-23, doi:10.1016/j.palaeo.2011.11.004.

Cramer, B. S., J. R. Toggweiler, J. D. Wright, M. E. Katz, and K. G. Miller (2009), Ocean overturning since the Late Cretaceous: Inferences from a new benthic foraminiferal isotope compilation. Paleoceanography, 24, PA4216, doi:10.1029/2008PA001683.

Dalziel, I.W.D. (1992), Antarctica: a tale of two supercontinents? Annu. Rev. Earth. Pl. Sc. 20, 501-526, doi:10.1146/annurev.ea.20.050192.002441.

Dalziel, I.W.D., and D.H. Elliot (1982), West Antarctica: problem child of Gondwanaland. Tectonics 1 (1), 3-19, doi:10.1029/TC001i001p00003.

Davies, T. A., B. P. Luyendyk, et al. (1974), Shipboard Scientific Party, site 258. In: Initial Rep. Deep Sea Drill. Proj. 26, Washington (U.S. Gov. Print. Off.), 359-414.

De Baar, H.J., M.P. Bacon, P.G. Brewer, and K.W. Bruland (1985), Rare earth elements in the Pacific and Atlantic Oceans. Geochim. Cosmochim. Acta 49 (9), 1943-1959, doi:10.1016/0016-7037(85)90089-4.

DeConto, R.M., E.C. Brady, J. Bergengren, and W.W. Hay (2000), Late Cretaceous climate, vegetation, and ocean interactions. In: B.T. Huber, K.G. MacLeod, and S.L. Wing 
(Eds.), Warm Climates in Earth History. Cambridge University Press, Cambridge, 275-296.

Donnadieu, Y., R. Pierrehumbert, R. Jacob, and F. Fluteau (2006), Modelling the primary control of paleogeography on Cretaceous climate. Earth Planet. Sci. Lett. 248 (1-2), 426-437, doi:10.1016/j.epsl.2006.06.007.

Dubinin, A. V. (2004), Geochemistry of Rare Earth Elements in the Ocean. Lithol. Miner. Resour. 39 (4), 289-307, doi:10.1023/B:LIMI.0000033816.14825.a2.

Dumitru, T.A., E.L. Miller, P.B. Osullivan, J.M. Amato, K.A. Hannula, A.T.Calvert, and P.B. Gans (1995), Cretaceous to recent extension in the Bering Strait region, Alaska. Tectonics 14 (3), 549-563, doi:10.1029/95TC00206.

Edgar, N.T., J.B. Saunders, et al. (1973). Shipboard Scientific Party, site 152. In: Initial Rep. Deep Sea Drill. Proj. 35, Washington (U.S. Gov. Print. Off.), 331-365.

Elderfield, H., and E.R. Sholkovitz (1987), Rare earth elements in the pore waters of reducing nearshore sediments. Earth Planet. Sci. Lett. 82 (3-4), 280-288, doi:10.1016/0012821X(87)90202-0.

Fleming, T.H., K.A. Foland, and D.H. Elliot (1995), Isotopic and chemical constraints on the crustal evolution and source signature of Ferrar magmas. Contrib. Mineral. Petr. 121 (3), 217-236, doi:10.1007/BF02688238.

Frank, M. (2002), Radiogenic isotopes: Tracers of past ocean circulation and erosional input. Rev. Geophys. 40 (1), 1-38, doi:10.1029/2000RG000094.

Frank, T.D., and M.A. Arthur (1999), Tectonic forcings of Maastrichtian ocean-climate evolution. Paleoceanography 14 (2), 103-117.

Frank, T.D., D.J. Thomas, R.M. Leckie, M.A. Arthur, P.R. Bown, K. Jones, J.A. Lees (2005), The Maastrichtian record from a depth transect on Shatski Rise (northwest Pacific): a 
tropical perspective on global ecological and oceanographic changes.

Paleoceanography 20, PA1008, 1-14, doi:10.1029/2004PA001052.

Friedrich, O., J. Erbache, K. Moriya, P.A. Wilson, and H. Kuhnert (2008), Warm saline intermediate waters in the Cretaceous tropical Atlantic Ocean. Nat. Geosci. 1, 453457, doi:10.1038/ngeo217.

Friedrich, O., R.D. Norris, J. Erbacher (2012), Evolution of middle to Late Cretaceous oceans - A 55 m.y. record of Earth's temperature and carbon cycle. Geology 40 (2), 107-110, doi:10.1130/g32701.1.

Goldstein, S.L., and S.H. Hemming (2003), Long lived isotopic tracers in oceanography, paleoceanography, and ice sheet dynamics. In: H. Elderfield, and K.K. Turekian (Eds.), Treatise on Geochemistry. Elsevier, New York. 453-489, doi:10.1016/B0-08043751-6/06179-X.

Goldstein, S.L., and R.K. O'nions (1981), Nd and Sr isotopic relationships in pelagic clays and ferromanganese deposits. Nature 292, 324-327, doi:10.1038/292324a0.

Gradstein, F.M., J.G. Ogg, M. Schmitz, and G. Ogg (2012), The Geologic Time Scale 2012. Elsevier, New York, N.Y., 1176 pp.

Grandjean, P., H. Cappetta, A. Michard, and F. Albarède (1987), The assessment of REE patterns and $143 \mathrm{Nd} / 144 \mathrm{Nd}$ ratios in fish remains. Earth Planet. Sci. Lett. 84 (2-3), 181-196, doi:10.1016/0012-821X(87)90084-7.

Guiraud, M., A. Buta-Neto, and D. Quesne (2010), Segmentation and differential post-rift uplift at the Angola margin as recorded by the transform-rifted Benguela and obliqueto-orthogonal-rifted Kwanza basins. Mar. Petrol. Geol. 27 (5), 1040-1068, doi:10.1016/j.marpetgeo.2010.01.017.

Gutjahr, M., M. Frank, C.H. Stirling, V. Klemm, T. Van de Flierdt, and A.N. Halliday (2007), Reliable extraction of a deepwater trace metal isotope signal from $\mathrm{Fe}-\mathrm{Mn}$ 
oxyhydroxide coatings of marine sediments. Chem. Geol. 242 (3-4), 351-370, doi:10.1016/j.chemgeo.2007.03.021.

Gutjahr, M., B.A.A. Hoogakker, M. Frank, and I.N. McCave (2010), Changes in north Atlantic deep water strength and bottom water masses during marine isotope stage 3 (45-35 ka BP). Quat. Sci. Rev. 29 (19-20), 2451-2461, doi:10.1016/j.quascirev.2010.02.024.

Hague, A.M., D.J. Thomas, M. Huber, R. Korty, S.C Woodard, and L.B. Jones (2012), Convection of North Pacific deep water during Early Cenozoic. Geology 40 (6), 527530, doi:10.1130/G32886.1.

Haley, B.A., G.P. Klinkhammer, and J. Mc Manus (2004), Rare earth elements in pore waters of marine sediments. Geochim. Cosmochim. Acta 68 (6), 1265-1279, doi:10.1016/j.gca.2003.09.012.

Haley, B.A., G.P. Klinkhammer, and A.C. Mix (2005), Revisiting the rare earth elements in foraminiferal tests. Earth Planet. Sci. Lett. 239 (1-2), 79-97, doi:10.1016/j.eps1.2005.08.014.

Hallam, A. (1985), A review of Mesozoic climates. J. Geol. Soc. 142, 433-445, doi:10.1144/gsjgs.142.3.0433.

Hamilton, N. (1990), Mesozoic magnetostratigraphy of Maud Rise, Antarctica. In: P. F Barker, J.P. Kennett, et al., Proc. Ocean Drill. Program Sci. Results 113, College Station, TX (Ocean Drilling Program), 255-260.

Haq, B.U. (1976), Coccoliths in cores from the Bellinghausen abyssal plain and Antarctic continental rise (DSDP Leg 35). In: C.D. Hollister, C. Craddock, et al., Initial Rep. Deep Sea Drill. Proj. 35, Washington (U.S. Gov. Print. Off.), 557-567.

Harbert, W., M. Alexutin, S. Sokolov, K. Krylov, V. Grigoriev, A. Heiphetz, and R. Graham (2001), Paleomagnetism of Cretaceous units of the Mametchinskiy Peninsula, Kuyul 
Region, Northeastern Russia: implications for development and evolution of the northwest pacific basin. Tectonophysics 340 (3-4), 215-231, doi:10.1016/S00401951(01)00177-9.

Hay, W.W. (2008), Evolving ideas about the Cretaceous climate and ocean circulation.

Cretaceous Res. 29 (5-6), 725-753, doi:10.1016/j.cretres.2008.05.025.

Hay, W.W., and F.M. Beaudry (1973), Calcareous nannofossils - Leg 15, Deep Sea Drilling

Project. In: N.T. Edgar, J.B. Saunders, et al., Initial Rep. Deep Sea Drill. Proj. 35, Washington (U.S. Gov. Print. Off.), 625-683.

Hergt, J.M., B.W. Chappell, G.Faure, and T.M. Mensing (1989), The geochemistry of Jurassic dolerites from Portal Peak, Antarctica. Contrib. Mineral. Petr. 102 (3), 298 305, doi 10.1007/BF00373722.

Hodell, D.A., G.D. Kamenov, E.C. Hathorne, J.C. Zachos, U. Röhl, and T. Westerhold (2007), Variations in the strontium isotope composition of seawater during the Paleocene and early Eocene from ODP Leg 208 (Walvis Ridge). Geochem. Geophys. Geosyst. 8, Q09001, doi:10.1029/2007GC001607.

Hollister, C.D., C. Craddock, et al. (1976), Shipboard Scientific Party, site 323. In: Initial Rep. Deep Sea Drill. Proj. 35, Washington (U.S. Gov. Print. Off.), 63-125.

Horikawa, K., E.E. Martin, Y. Asahara, and T. Sagawa (2011), Limits on conservative behavior of $\mathrm{Nd}$ isotopes in seawater assessed from analysis of fish teeth from Pacific core tops. Earth Planet. Sci. Lett. 310 (1-2), 119-130, doi:10.1016/j.eps1.2011.07.018.

Huber, B.T. (1990), Maestrichtian planktonic foraminifer biostratigraphy of the Maud Rise (Weddell Sea, Antarctica), ODP Leg 113 Holes 689B and 690C. In: P.F. Barker, J.P. Kennett, et al., Proc. Ocean Drill. Program Sci. Results 113, College Station, TX (Ocean Drilling Program), 489-513. 
Huber, B.T. (1991), Planktonic foraminifer biostratigraphy of Campanian-Maestrichtian sediments from ODP Leg 114 Sites 698 and 700, southern South Atlantic. In: P.F. Ciesielski, Y. Kristoffersen, et al., Proc. Ocean Drill. Program Sci. Results 114, College Station, TX (Ocean Drilling Program), 281-297.

Huber, B.T., D.A. Hodell, and C.P. Hamilton (1995), Middle-Late Cretaceous climate of the southern high latitudes: stable isotopic evidence for minimal equator-to-pole thermal gradients. Geol. Soc. Am. Bull. 107 (10), 1164-1191, doi:10.1130/00167606(1995)107<1164:MLCCOT>2.3.CO;2.

Jackson, M.P.A., and M.R. Hudec (2005), Stratigraphic record of translation down ramps in a passive-margin salt detachment. J.Struct. Geol. 27 (5), 889-911, doi:10.1016/j.jsg.2005.01.010.

Jeandel, C. (1993), Concentration and isotopic composition of Nd in the South Atlantic ocean. Earth Planet. Sci. Lett. 117 (3-4), 581-591, doi:10.1016/0012-821X(93)90104-H.

Jeandel, C., T. Arsouze, F. Lacan, P. Téchiné, and J.-C. Dutay (2007), Isotopic Nd compositions and concentrations of the lithogenic inputs into the ocean: A compilation, with an emphasis on the margins. Chem. Geol. 239 (1-2), 156-164, doi:10.1016/j.chemgeo.2006.11.013.

Jeandel, C., J.K. Bishop, and A. Zindler (1995), Exchange of neodymium and its isotopes between seawater and small and large particles in the Sargasso Sea. Geochim. Cosmochim. Acta 59 (3), 535-547, doi:10.1016/0016-7037(94)00367-U.

Jiménez Berrocoso, Á., K.G. MacLeod, E.E. Martin, E. Bourbon, C. Isaza Londoño, and C. Basak (2010), Nutrient trap for the Late Cretaceous organic-rich black shales in the tropical north Atlantic. Geology 38 (12), 1111-1114, doi:10.1130/G31195.1.

Jones, E.J.W., S.C. Cande, and F. Spathopoulos (1995), Evolution of a major oceanographic pathway: The equatorial Atlantic. In: R.A. Scrutton, et al. (Eds.), The tectonics, 
sedimentation and palaeoceanography of the North Atlantic region. Geol. Soc. London Spec. Publ. 90, 199-213, doi:10.1144/GSL.SP.1995.090.01.12.

Karpoff, A.M., C. Destrigneville, and P. Stille (2007), Clinoptilolite as a new proxy of enhanced biogenic silica productivity in lower Miocene carbonate sediments of the Bahamas platform: Isotopic and thermodynamic evidence. Chem. Geol. 245 (3-4), 285-304, doi:10.1016/j.chemgeo.2007.08.011.

Killick, R., and I.A. Eckley (2014), Changepoint: An R Package for Changepoint Analysis. J. Stat. Softw. 58 (3), 1-19.

Lacan, F., and C. Jeandel (2001), Tracing Papua New Guinea imprint on the central Equatorial Pacific Ocean using neodymium isotopic compositions and Rare Earth Element patterns. Earth Planet. Sci. Lett. 186 (3-4), 497-512, doi:10.1016/S0012821X(01)00263-1.

Lacan, F., and C. Jeandel (2005a), Acquisition of the neodymium isotopic composition of the North Atlantic Deep Water. Geochem. Geophys. Geosyst. 6 (12), Q12008, doi:10.1029/2005GC000956.

Lacan, F., and C. Jeandel (2005b), Neodymium isotopes as a new tool for quantifying exchange fluxes at the continent - ocean interface. Earth Planet. Sci. Lett. 232 (3-4), 245-257, doi:10.1016/j.eps1.2005.01.004.

Larson, R.L, and W.C. Pitman (1972), World-wide correlation of Mesozoic magnetic anomalies, and its implications. Geol. Soc. Am. Bull. 83 (12), 3645-3662, doi:10.1130/0016-7606(1972)83[3645:WCOMMA]2.0.CO;2.

Le Houëdec, S., L. Meynadier, and C.J. Allegre (2009), 80 My high resolution Nd isotopes record in Western Pacific (ODP 807). Geochim. Cosmochim. Acta 73 (13), A741A741. 
Le Houëdec, S., L. Meynadier, J.P. Cogné, C.J. Allegre, and A.T. Gourlan (2012), Oceanwide imprint of large tectonic and oceanic events on seawater Nd isotope composition in the Indian Ocean from 90 to 40 Ma. Geochem. Geophys. Geosyst. 13 (6), Q06008, doi:10.1029/2011GC003963.

Lugmair, G.W., and K. Marti (1977), Sm-Nd-Pu timepieces in the Angra dos Reis meteorite. Earth Planet. Sci. Lett. 35 (2), 273-284, doi:10.1016/0012-821X(77)90131-5.

Mackey, K.G., K. Fujita, L.V. Gunbina, V.N. Kovalev, V.S. Imaev, B.M. Kozmin, and L.P. Imaeva (1997), Seismicity of the Bering Strait region: Evidence for a Bering block. Geology 25 (11), 979-982, doi:10.1130/00917613(1997)025<0979:SOTBSR>2.3.CO;2.

MacLeod, K.G., C. Isaza Londono, E.E. Martin, Á. Jiménez Berrocoso, and C. Basak (2011), Changes in North Atlantic circulation at the end of the Cretaceous greenhouse. Nat. Geosci. 4, 779-782, doi:10.1038/ngeo1284.

MacLeod, K.G., E.E. Martin, and S.W. Blair (2008), Nd isotopic excursion across Cretaceous ocean anoxic event 2 (Cenomanian-Turonian) in the tropical North Atlantic. Geology 36, 811-814, doi:10.1130/G24999A.1.

Martin, E.E., S.W. Blair, G.D. Kamenov, H.D. Scher, E. Bourbon, C. Bask, and D.N. Newkirk (2010), Extraction of Nd isotopes from bulk deep sea sediments for paleoceanographic studies on Cenozoic time scales. Chem. Geol. 269 (3-4), 414-431, doi:10.1016/j.chemgeo.2009.10.016.

Martin, E.E., and B.A. Haley (2000), Fossil fish teeth as proxies for seawater $\mathrm{Sr}$ and $\mathrm{Nd}$ isotopes. Geochim. Cosmochim. Acta 64 (5), 835-847, doi:10.1016/S00167037(99)00376-2. 
Martin, E.E., K.G. MacLeod, Á. Jiménez Berrocoso, and E. Bourbon (2012), Water mass circulation on Demerara Rise during the Late Cretaceous based on Nd isotopes. Earth Planet. Sci. Lett. 327-328, 111-120, doi:10.1016/j.eps1.2012.01.037.

Martin, E.E., and H.D. Scher (2004), Preservation of seawater Sr and Nd isotopes in fossil fish teeth: bad news and good news. Earth Planet. Sci. Lett. 220 (1-2), 25-39, doi:10.1016/S0012-821X(04)00030-5.

Moiroud M., E. Pucéat, Y. Donnadieu, G. Bayon, K. Moriya, J.-F. Deconinck, and M. Boyet (2013), Evolution of the neodymium isotopic signature of neritic seawater on a northwestern Pacific margin: new constrains on possible end-members for the composition of deep-water masses in the Late Cretaceous ocean. Chem. Geol. 356, 160-170, doi:10.1016/j.chemgeo.2013.08.008.

Murphy D.P., and D.J. Thomas (2012), Cretaceous deep-water formation in the Indian sector of the Southern Ocean. Paleoceanography 27, PA1211, doi:10.1029/2011PA002198.

Murphy, D.P., and D.J. Thomas (2013), The evolution of Late Cretaceous deep-ocean circulation in the Atlantic basins: Neodymium isotope evidence from South Atlantic drill sites for tectonic controls. Geochem. Geophys. Geosyst. 14 (12), 5323-5340, doi:10.1002/2013GC004889.

Nakai, S., A.N. Halliday, and D.K. Rea (1993), Provenance of dust in the Pacific Ocean. Earth Planet. Sci. Lett. 119 (1-2), 143-157, doi:10.1016/0012-821X(93)90012-X.

Négrel, P., J. Casanova, and J. Brulhet (2006), REE and Nd isotope stratigraphy of a Late Jurassic carbonate platform, eastern Paris Basin, France. J. Sediment. Res. 76 (3), 605617, doi:10.2110/jsr.2006.050.

O’Connor, J.M., and R.A. Duncan (1990), Evolution of the Walvis Ridge Rio-Grande Rise hot-spot system - Implications for African and South-American plate motions over 
plumes. J. Geophys. Res.-Sol. Ea. 95 (B11), 17475-17502, doi:10.1029/JB095iB11p17475.

Osborne, A.H., B.A. Haley, E.C. Hathorne, S. Flögel, and M. Frank (2014). Neodymium isotopes and concentrations in Caribbean seawater: Tracing water mass mixing and continental input in a semi-enclosed ocean basin. Earth Planet. Sci. Lett. 406, 174 186, doi:10.1016/j.eps1.2014.09.011.

Otto-Bliesner, B. L., E. C. Brady, and C. Shields (2002), Late Cretaceous ocean: Coupled simulations with the National Center for Atmospheric Research Climate System Model. J. Geophys. Res.-Atmos 107 (D2), doi:10.1029/2001JD000821.

Picard, S., C. Lécuyer, J.A. Barrat, J.P. Garcia, G. Dromart, and S.M.F. Sheppard (2002), Rare earth element contents of Jurassic fish and reptile teeth and their potential relation to seawater composition (Anglo-Paris Basin, France and England). Chem. Geol. 186 (1-2), 1-16, doi:10.1016/S0009-2541(01)00424-7.

Piepgras, D.J., and S.B. Jacobsen (1988), The isotopic composition of neodymium in the North Pacific. Geochim. Cosmochim. Acta 52 (6), 1373-1381, doi:10.1016/00167037(88)90208-6.

Piepgras, D.J., and S.B. Jacobsen (1992), The behavior of rare-earth elements in seawater precise determination of variations in the North Pacific water column. Geochim. Cosmochim. Acta 56 (5), 1851-1862, doi:10.1016/0016-7037(92)90315-A.

Piepgras, D.J., and G.J. Wasserburg (1982), Isotopic composition of neodymium in waters from the Drake Passage. Science 217, 207-217, doi:10.1126/science.217.4556.207.

Piepgras, D.J., and G.J. Wasserburg (1987), Rare earth element transport in the western North Atlantic inferred from Nd isotopic observations. Geochim. Cosmochim. Acta 51 (5), 1257-1271, doi:10.1016/0016-7037(87)90217-1. 
Piepgras, D.J., G.J. Wasserburg, and E.G. Dasch (1979), The isotopic composition of Nd in different ocean masses. Earth Planet. Sci. Lett. 45 (2), 223-236, doi:10.1016/0012$821 X(79) 90125-0$.

Pin, C., and J.F.S. Zalduegi (1997), Sequential separation of light rare-earth elements, thorium and uranium by miniaturized extraction chromatography: Application to isotopic analyses of silicate rocks. Anal. Chim. Acta 339 (1-2), 79-89, doi:10.1016/S00032670(96)00499-0.

Pindell, J.L., and L. Kennan (2009), Tectonic evolution of the Gulf of Mexico, Caribbean and northern South America in the mantle reference frame: an update. In: K.H. James, M.A. Lorente, J.L. Pindell (Eds.), The Origin and Evolution of the Caribbean Plate. Geol. Soc. Spec. Publ. 328, 1-55, doi:10.1144/SP328.1.

Piotrowski, A.M., S.L. Goldstein, S.R. Hemming, and R.G. Fairbanks (2004), Intensification and variability of ocean thermohaline circulation through the last deglaciation. Earth Planet. Sci. Lett. 225, 205-220, doi:10.1016/j.eps1.2004.06.002.

Piotrowski, A.M., A. Galy, J.A.L. Nicholl, N. Roberts, D.J. Wilson, J.A. Clegg, and J. Yu (2012), Reconstructing deglacial North and South Atlantic deep water sourcing using foraminiferal Nd isotopes. Earth Planet. Sci. Lett. 357-358, 289-297, doi:10.1016/j.eps1.2012.09.036.

Piotrowski, A.M., S.L. Goldstein, S.R. Hemming, R.G. Fairbanks, and D.R. Zylberberg (2008), Oscillating glacial northern and southern deep water formation from combined neodymium and carbon isotopes. Earth Planet. Sci. Lett. 272 (1-2), 394-405 doi:10.1016/j.epsl.2008.05.011.

Poulsen, C. J., E.J. Barron, M.A. Arthur, and W.H. Peterson (2001), Response of the midCretaceous global oceanic circulation to tectonic and $\mathrm{CO}_{2}$ forcings. Paleoceanography 16 (6), 576-592, doi:10.1029/2000PA000579. 
Premoli Silva, I., and H.M. Bolli (1973), Late Cretaceous to Eocene planktonic foraminifera and stratigraphy of leg 15 sites in the Caribbean Sea. In: N.T. Edgar, J.B. Saunders, et al., Initial Rep. Deep Sea Drill. Proj. 35, Washington (U.S. Gov. Print. Off.), 499547.

Pucéat, E., C.Lécuyer, S.M.F. Sheppard, G. Dromart, S. Reboulet, and P. Grandjean (2003), Thermal evolution of Cretaceous Tethyan marine waters inferred from oxygen isotope composition of fish tooth enamels. Paleoceanography 18 (2), doi:10.1029/2002PA000823.

Pucéat, E., Y. Donnadieu, G. Ramstein, F. Fluteau, and F. Guillocheau (2005), Numerical evidence for thermohaline circulation reversals during the Maastrichtian. Geochem. Geophys. Geosyst. 6 (11), Q11012, doi:10.1029/2005GC000998.

Renne, P.R., M. Ernesto, I.G. Pacca, R.S. Coe, J.M. Glen, M. Prévot, and M. Perrin (1992), The age of Paraná flood volcanism, rifting of Gondwanaland, and the JurassicCretaceous boundary. Science 258 (5084), 975-979, doi:10.1126/science.258.5084.975.

Reynard, B., C. Lécuyer, and P. Grandjean (1999), Crystal-chemical controls on rare-earth element concentrations in fossil biogenic apatites and implications for paleoenvironmental reconstructions. Chem. Geol. 155 (3-4), 233-241, doi:10.1016/S0009-2541(98)00169-7.

Rohde, J.K., P. van den Bogaard, K. Hoernle, F. Hauff, and R. Werner (2012), Evidence for an age progression along the Tristan-Gough volcanic track from new ${ }^{40} \mathrm{Ar} /{ }^{39} \mathrm{Ar}$ ages on phenocryst phases. Tectonophysics 604, 60-71, doi:10.1016/j.tecto.2012.08.026.

Robinson, S.A., D.P. Murphy, D. Vance, and D.J. Thomas (2010), Formation of 'Southern Component Water' in the Late Cretaceous: Evidence from Nd-isotopes. Geology 38 (10), 871-874, doi:10.1130/G31165.1. 
Robinson, S.A., and D. Vance (2012), Widespread and synchronous change in deep-ocean circulation in the North and South Atlantic during the Late Cretaceous. Paleoceanography 27, PA1102, doi:10.1029/2011PA002240.

Roy, M., T. van de Flierdt, S.R. Hemming, and S.L. Goldstein (2007), ${ }^{40} \mathrm{Ar} /{ }^{39} \mathrm{Ar}$ ages of hornblende grains and bulk $\mathrm{Sm} / \mathrm{Nd}$ isotopes of circum-Antarctic glacio-marine sediments: Implications for sediment provenance in the southern ocean. Chem. Geol. 244 (3-4), 507-519, doi:10.1016/j.chemgeo.2007.07.017.

Sen, A., and M.S. Srivastava (1975), On tests for detecting change in mean. Ann. Stat. 3 (1), 98-108, doi:10.1007/BF02504665.

Seton, M., N. Flament, J. Whittaker, R.D. Müller, M. Gurnis, and D.J. Bower (2015), Ridge subduction sparked reorganization of the Pacific plate-mantle system 60-50 million years ago. Geophys. Res. Let. 42 (6), 1732-1740, doi:10.1002/2015GL063057.

Sewall, J.O., R.S.W. van de Wal, K. van der Zwan, C. van Oosterhout, H.A. Dijkstra, and C.R. Scotese (2007), Climate model boundary conditions for four Cretaceous time slices. Clim.Past 3, 647-657, doi:10.5194/cp-3-647-2007.

Shaw, H.F., and G.J. Wasserburg (1985), Sm, Nd in marine carbonates and phosphates. Geochim. Cosmochim. Acta 49 (2), 503-518, doi:10.1016/0016-7037(85)90042-0.

Shields, G., and P. Stille (2001), Diagenetic constraints on the use of cerium anomalies as palaeoseawater redox proxies: an isotopic and REE study of Cambrian phosphorites. Chem. Geol. 175 (1-2), 29-48, doi:10.1016/S0009-2541(00)00362-4.

Shimizu, H., K. Tachikawa, A. Masuda, and Y. Nozaki (1994), Cerium and neodymium isotope ratios and REE patterns in seawater from the North Pacific Ocean. Geochim. Cosmochim. Acta 58 (1), 323-333, doi:10.1016/0016-7037(94)90467-7.

Soudry, D., C.R. Glenn, Y. Nathan, I. Segal, and D. Vonderhaar (2006), Evolution of Tethyan phosphogenesis along the northern edges of the Arabian-African shield during the 
Cretaceous-Eocene as deduced from temporal variations of $\mathrm{Ca}$ and $\mathrm{Nd}$ isotopes and rates of P accumulation. Earth-Sci. Rev. 78 (1-2), 27-57, doi:10.1016/j.earscirev.2006.03.005.

Soudry, D., Y. Nathan, and CR. Glenn (2005), Phosphorus accumulation rates in the Upper Cretaceous-Eocene of the southern Tethys margin - a case study of temporal fluctuations in phosphogenesis and rates of phosphate fluxes. Final scientific report. Submitted to the US-Israel Binational Science Foundation. Geological Survey Israel, Report GSI/01/2005.

Staudigel, H., P. Doyle, and A. Zindler (1985), Sr and Nd isotope systematics in fish teeth. Earth Planet. Sci. Lett. 76 (1-2), 45-46, doi:10.1016/0012-821X(85)90147-5.

Steuber, T., M. Rauch, J.P. Masse, J. Graaf, and M. Malkoč (2005), Low-latitude seasonality of Cretaceous temperatures in warm and cold episodes. Nature 437, 1341-1344, doi:10.1038/nature04096.

Stewart, K., S. Turner, S. Kelley, C. Hawkesworth, L. Kirstein, and M. Mantovani (1996), 3$\mathrm{D},{ }^{40} \mathrm{Ar} /{ }^{39} \mathrm{Ar}$ geochronology in the Paraná continental flood basalt province. Earth Planet. Sci. Lett. 143 (1-4), 95-109, doi:10.1016/0012-821X(96)00132-X.

Tachikawa, K., V. Athias, and C. Jeandel (2003), Neodymium budget in the modern ocean and paleo-oceanographic implications. J. Geophys. Res.-Oceans 108 (C8), doi:10.1029/1999JC000285.

Tachikawa, K., C. Jeandel, and M. Roy-Barman (1999), A new approach to the Nd residence time in the ocean: the role of atmospheric inputs. Earth Planet. Sci. Lett. 170 (4), 433446, doi:10.1016/S0012-821X(99)00127-2.

Tachikawa, K., T. Toyofuku, I. Basile-Doelsch, and T. Delhaye (2013), Microscale neodymium distribution in sedimentary planktonic foraminiferal tests and associated 
mineral phases. Geochim. Cosmochim. Acta 100, 11-23, doi:10.1016/j.gca.2012.10.010.

Tanaka, T., S. Togashi, H. Kamioka, H. Amakawa, H. Kagami, T. Hamamoto, M. Yuhara, Y. Orihashi, S. Yoneda, H. Shimizu, T. Kunimaru, K. Takahashi, T. Yanagi, T. Nakano, H. Fujimaki, R. Shinjo, Y. Asahara, M. Tanimizu, C. Dragusanu (2000), JNdi-1: A neodymium isotopic reference in consistency with LaJolla neodymium, Chem. Geol., 168, 279-281, doi:10.1016/S0009-2541(00)00198-4.

Taylor, S.R., and S.M. McLennan (1985), The Continental Crust: Its Composition and Evolution. Blackwell, Oxford, 312 pp.

Thierstein, H. R. (1974), Calcareous Nannoplankton - Leg 26, Deep Sea Drilling Project. In: T. A. Davies, B. P. Luyendyk, et al., Initial Rep. Deep Sea Drill. Proj. 26, Washington (U.S. Gov. Print. Off.), 619-667.

Thomas, D.J. (2004), Evidence for Production of North Pacific Deep Waters During the early Cenozoic Greenhouse. Nature 430, 65-68, doi:10.1038/nature02639.

Thomas, D.J., T.J. Bralower, and C.E. Jones (2003), Neodymium isotopic reconstruction of late Paleocene-Early Eocene thermohaline circulation. Earth Planet. Sci. Lett. 209 (34), 309-322, doi:10.1016/S0012-821X(03)00096-7.

Thomas, D.J., R. Korty, M. Huber, J.A. Schubert, and B. Haines (2014), Nd isotopic structure of the Pacific Ocean 70-30 Ma and numerical evidence for vigorous ocean circulation and ocean heat transport in a greenhouse world. Paleoceanography 29 (5), 454-469, doi:10.1002/2013PA002535.

Thomas, D.J., M. Lyle, T.C. Moore Jr., and D.K. Rea (2008), Paleogene deepwater mass composition of the tropical Pacific and implications for thermohaline circulation in a greenhouse world. Geochem. Geophys. Geosyst. 9 (2), Q02002, doi:10.1029/2007GC001748. 
Van de Flierdt, T., S.L. Goldstein, S.R. Hemming, M. Roy, M. Frank, and A.N. Halliday (2007), Global neodymium-hafnium isotope systematics - revisited. Earth Planet. Sci. Lett. 259, 432-441, doi:10.1016/j.eps1.2007.05.003.

Vaughan, A.P.M., and B.C. Storey (2000), The eastern Palmer Land shear zone: a new terrane accretion model for the Mesozoic development of the Antarctic Peninsula. J. Geol. Soc. London 157, 1243-1256, doi:10.1144/jgs.157.6.1243.

Whitechurch, H., R. Montigny, J.H. Sevigny, M. Storey, and V.J.M. Salters (1992), K-Ar and Global neodymium-hafnium isotope systematics - revisited ${ }^{40} \mathrm{Ar} /{ }^{39} \mathrm{Ar}$ ages of central Kerguelen Plateau basalts. Proc. Ocean Drill. Program Sci. Results 120, College Station, TX (Ocean Drilling Program), 71-77.

Whittaker, S.G., and T.K. Kyser (1993), Variations in the neodymium and strontium isotopic composition and REE content molluscan shells from the Cretaceous Western Interior seaway. Geochim. Cosmochim. Acta 57, 4003-4014, doi:10.1016/00167037(93)90349-2.

Wright, J., R.S. Seymour, and H.F. Shaw (1984), REE and Nd isotopes in conodont apatites: Variation with geological age and depositional environment. In: D.L. Clarck (Ed.), Conodont Biofacies and Provincialism. Geol. Soc. Am. Spec. Pap. 196, 325-340, doi:10.1130/SPE196-p325.

Zhang, Y., F. Lacan, and C. Jeandel (2008), Dissolved rare earth elements tracing lithogenic inputs over the Kerguelen Plateau (Southern Ocean). Deep-Sea Research, Part 2, Topic. Stud. Oceanogr. 55 (5-7), 638-652, doi:10.1016/j.dsr2.2007.12.029.

Zhuravlev, D.Z., A.A Tsvetkov, A.Z. Zhuravlev, N.G. Gladkov, and I.V. Chernyshev (1987), ${ }^{143} \mathrm{Nd} /{ }^{144} \mathrm{Nd}$ and ${ }^{87} \mathrm{Sr} /{ }^{86} \mathrm{Sr}$ ratios in recent magmatic rocks of the Kurile island arc. Chem. Geol. (Isot. Geosci. Section) 66 (3-4), 227-243, doi:10.1016/01689622(87)90044-3. 


\section{Figure captions}

Figure 1. Reconstruction of the paleogeography for (A) the Turonian ( $90 \mathrm{Ma})$ and (B) the Maastrichtian ( 70 Ma) (after Sewall et al., 2007). The dots indicate the positions of previously published Late Cretaceous to Paleocene Nd isotopic data from neritic sites (in white), and oceanic deep and intermediate sites (in grey and black). The DSDP/ODP sites of the present study are located by coloured stars. NCW: Northern Component Water; SCW: Southern Component Water. The red areas indicate other zones of deep-water production suggested in the literature.

Figure 2. Rare earth element (REE) patterns for the fossil fish debris ('fish'), HH-extraction of foraminifera ('HH foram') and residue fraction samples ('residue') from this study, normalised to Post-Archean Australian Shale (PAAS) (Taylor and McLennan, 1985). Reference spectra from the literature of Fe-Mn nodules are from Axelsson et al. (2002), AAleached carbonates are from Martin et al. (2010), HH-extracted sediment oxide coatings from Bayon et al. (2004), Gutjahr et al. (2010) and Martin et al. (2010), foraminifera coatings from Bayon et al. (2004), AA+HH leaching residues are from Karpoff et al. (2007) and Martin et al. (2010), clay samples are from Chamley and Bonnot-Courtois (1981), and modern seawater sample is from Zhang et al. (2008) (for this sample, values were multiplied by $10^{6}$ to allow comparison with the other spectra). The Oligocene samples from Site 690 labelled '690,9-5' and '690,10-5' are from Martin et al. (2010).

Figure 3. Plot of $\varepsilon_{\mathrm{Nd}(\mathrm{t})}$ of fish remains (circles outlined in black), HH-extraction of foraminifera (solid circles) and residue fraction (open diamonds) versus modern depth in drill hole below sea-floor (mbsf).

Figure 4. Comparison of PAAS-normalised HREE/LREE $(\mathrm{Tm}+\mathrm{Yb}+\mathrm{Lu}) /(\mathrm{La}+\mathrm{Pr}+\mathrm{Nd}) \mathrm{vs}$ MREE/MREE* (Gd+Tb+Dy/average of HREE and LREE) of (A) different archives available 
in the literature, along with (B) those of fish debris samples, (C) HH-extraction of foraminifera, and (D) and residues measured in this study. The coloured ellipses correspond to the typical domains of carbonate calcite ('Carbonates'), authigenic oxides of carbonates ('Oxides') and the carbonate detrital fraction ('Residue'), as presented in Martin et al. (2010). Phosphorite samples are from Hein et al. (1999), Shields and Stille (2001); authigenic Fe-Mn oxides extracted from bulk sediments are from Bayon et al., (2002), Bayon et al., (2004), Négrel et al., (2006), Gutjahr et al., (2007), Gutjahr et al., (2010), Martin et al., (2010); HHextraction of foraminifera are from Bayon et al., (2004), Charbonnier et al. (2012); fish teeth are from Grandjean et al., (1987), Picard et al., (2002), Martin et al., (2010), Charbonnier et al. (2012); Fe-Mn nodules are from Axelsson et al., (2002), Gutjahr et al., (2010); limestone samples are from Kawabe et al. (1991); data of foraminifera calcite are from Haley et al. (2005); modern microbialite and coral calcite samples are from Webb and Kamber (2000); molluscs shells are from Whittaker and Kyser (1993); modern seawater are from De Baar et al., (1985), Piepgras and Jacobsen (1992), Arraes-Mescoff et al., (2001), Lacan and Jeandel (2005a), Zhang et al., (2008); pore water are from Elderfield and Sholkovitz (1987), Haley et al., (2004); and detrital fraction are from Elderfield and Sholkovitz (1987), Bayon et al., (2002), Gutjahr et al., (2007), Charbonnier et al. (2012).

Figure 5. Plot of $\varepsilon_{\mathrm{Nd}(\mathrm{t})}$ data (A) for Site 690 and (B) Site 323 from this study, together with data available in the literature, vs. absolute age (Gradstein et al., 2012). Values from the literature are from Voigt et al. (2013), Murphy and Thomas (2013) and Thomas et al. (2014), and were recalculated with the same age models and standards as those used to calculate the values of this study.

Figure 6. Compilation of oceanic $\varepsilon_{\mathrm{Nd}(\mathrm{t})}$ data available in the literature for the Late Cretaceous and the Paleogene periods in (A) the North Atlantic, (B) the South Atlantic and Indian sector, and $(\mathbf{C})$ the Pacific Ocean. Published data are inferred from fossil fish remains and oxide 
coatings of bulk sediments, and are presented along with the data acquired in the present study (yellow-filled circles). Thin lines (symbols) and regular text (site name) mean intermediate paleodepths (from 500 to 2000 m); thick black lines and bold characters indicate deep-water sites (paleodepths beneath $2000 \mathrm{~m}$ ). All data are fully reported in Table S1 of the Supplementary information. References are indicated for each site in the legend (Thomas et al., 2003; 2008; 2014; Thomas, 2004; Frank et al., 2005; MacLeod et al., 2008; 2011; Jiménez Berrocoso et al., 2010; Robinson et al., 2010; Hague et al., 2012; Le Houëdec et al., 2009; 2012; Martin et al., 2010; 2012; Murphy and Thomas, 2012; 2013; Robinson and Vance, 2012; Voigt et al., 2013). $\varepsilon_{\mathrm{Nd}(\mathrm{t})}$ values and ages were recalculated using age models calibrated to the GTS2012 (Gradstein et al., 2012) and the values of CHUR from Bouvier et al. (2008). Means (solid lines) and 95\% confidence intervals (dotted lines) in the coloured shadow boxes outline the main variations of the $\varepsilon_{\mathrm{Nd}}$ data for each oceanic basin, as generated using the free R software together with the changepoint package (Killick and Eckley, 2014). The dotted squares show radiogenic data interpreted to be the consequence of volcanogenic inputs. Early Maastrichtian paleogeography ( 70 Ma) is after Sewall et al. (2007).

Figure 7. Structural framework of the modern South Atlantic Ocean, displaying the main volcanic units and corresponding ages (after Renne et al., 1992; Stewart et al., 1996; O’Connor and Duncan 1990; Rohde et al., 2013). (A) South Atlantic Ocean (equatorial segment), (B) South Atlantic Ocean (central segment), (C) South Atlantic Ocean (south segment), (D) South Atlantic Ocean (Falkland segment).

Figure 8. Turonian bathymetry for the South Atlantic contoured in $1000 \mathrm{~m}$ interval (after O’Connor and Duncan, 1990).

\section{Table captions}


Table 1. Tabulated neodymium $(\mathrm{Nd})$ isotopic data generated in this study.

Table 2. Tabulated REE data generated in this study. 

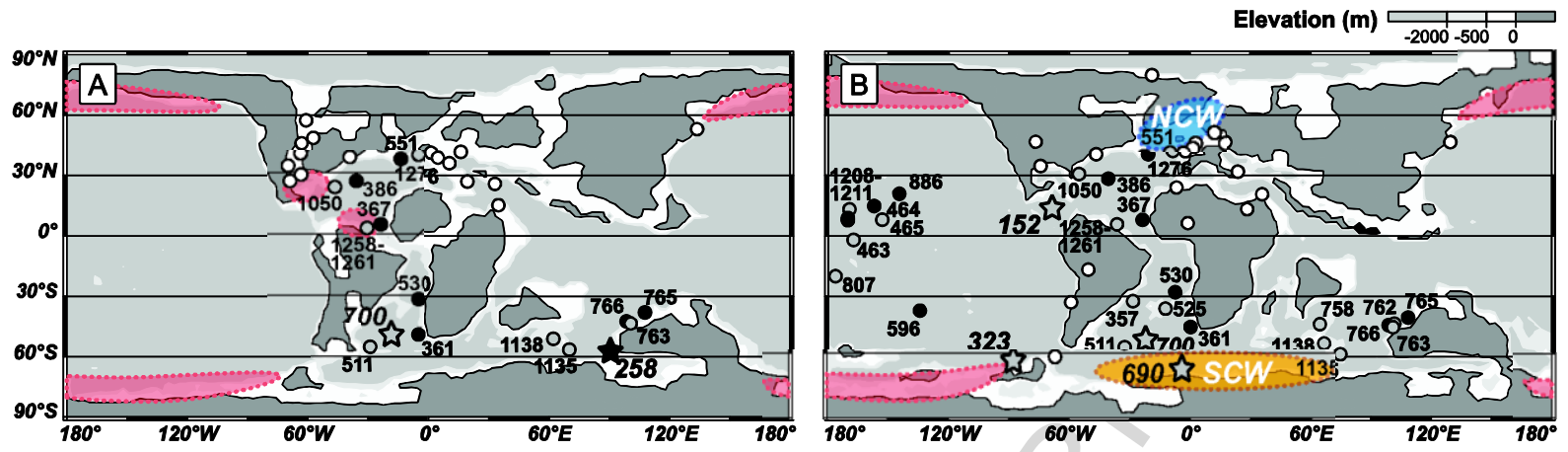

Figure 1 

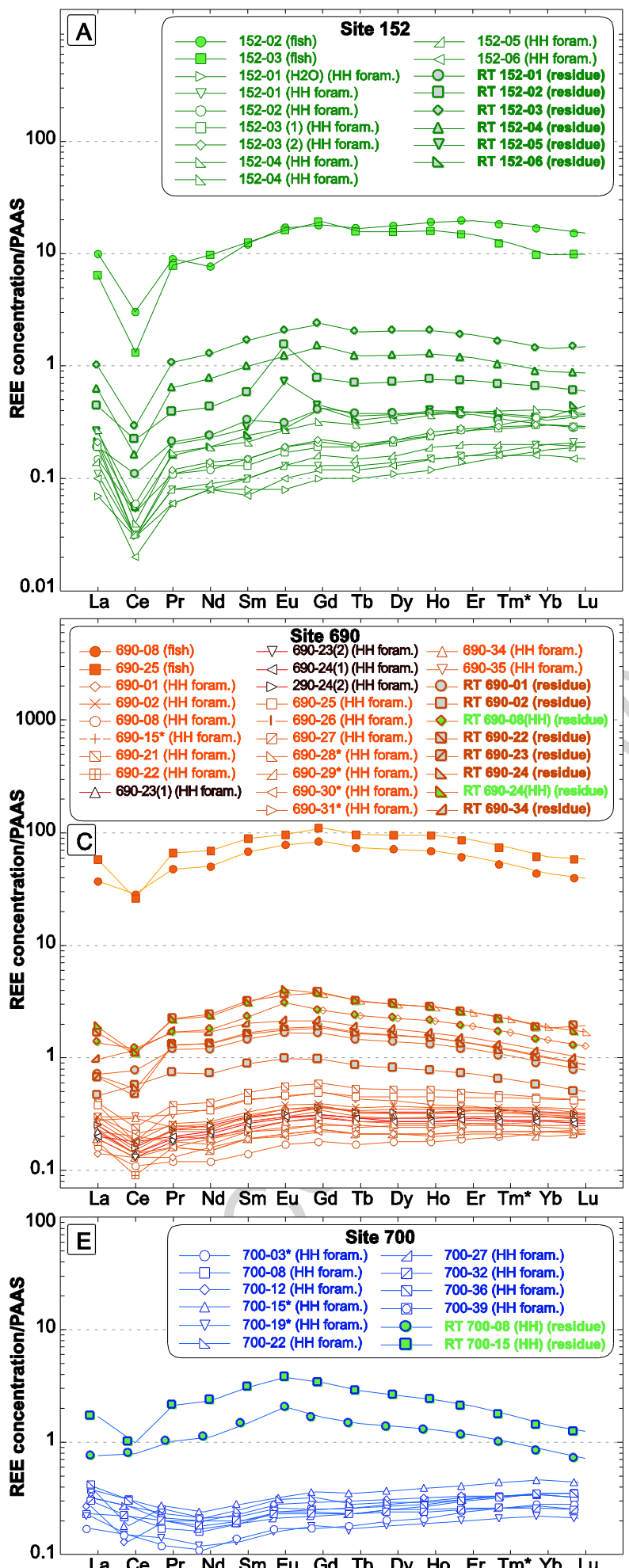

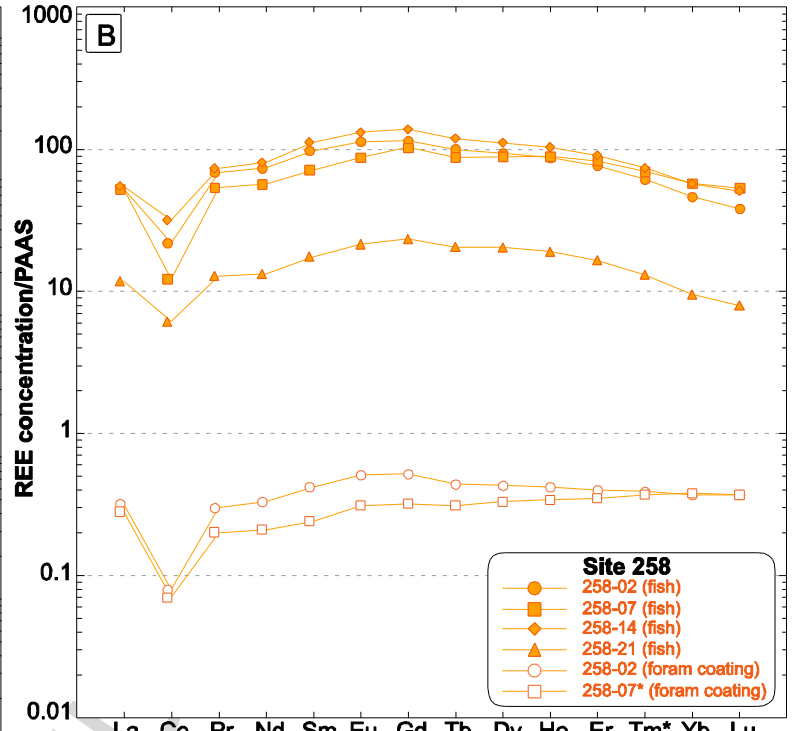

La Ce $\operatorname{Pr}{ }^{\prime} \mathrm{Nd}$ Sm Eu Gd Tb Dy Ho $\mathrm{Er} \mathrm{Tm}^{*} \mathrm{~Tb}^{\prime} \mathrm{Lu}^{\prime}$ $1000=$
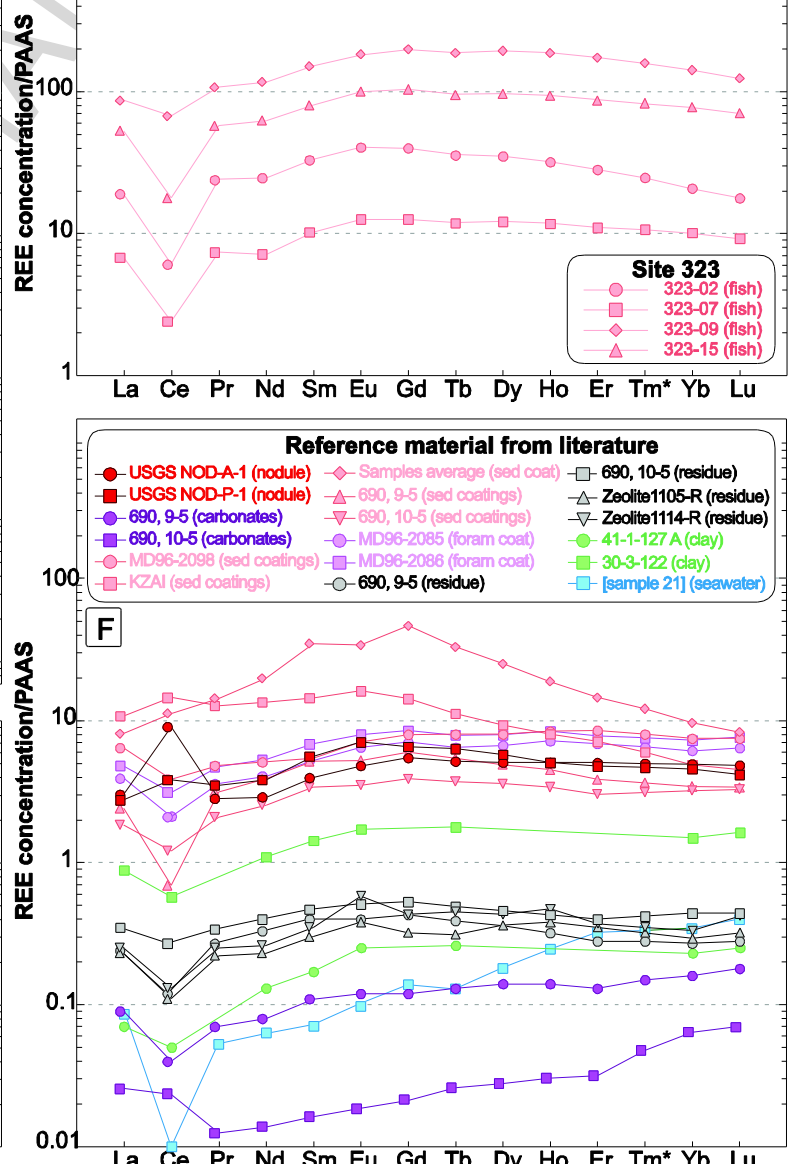

Figure 2 


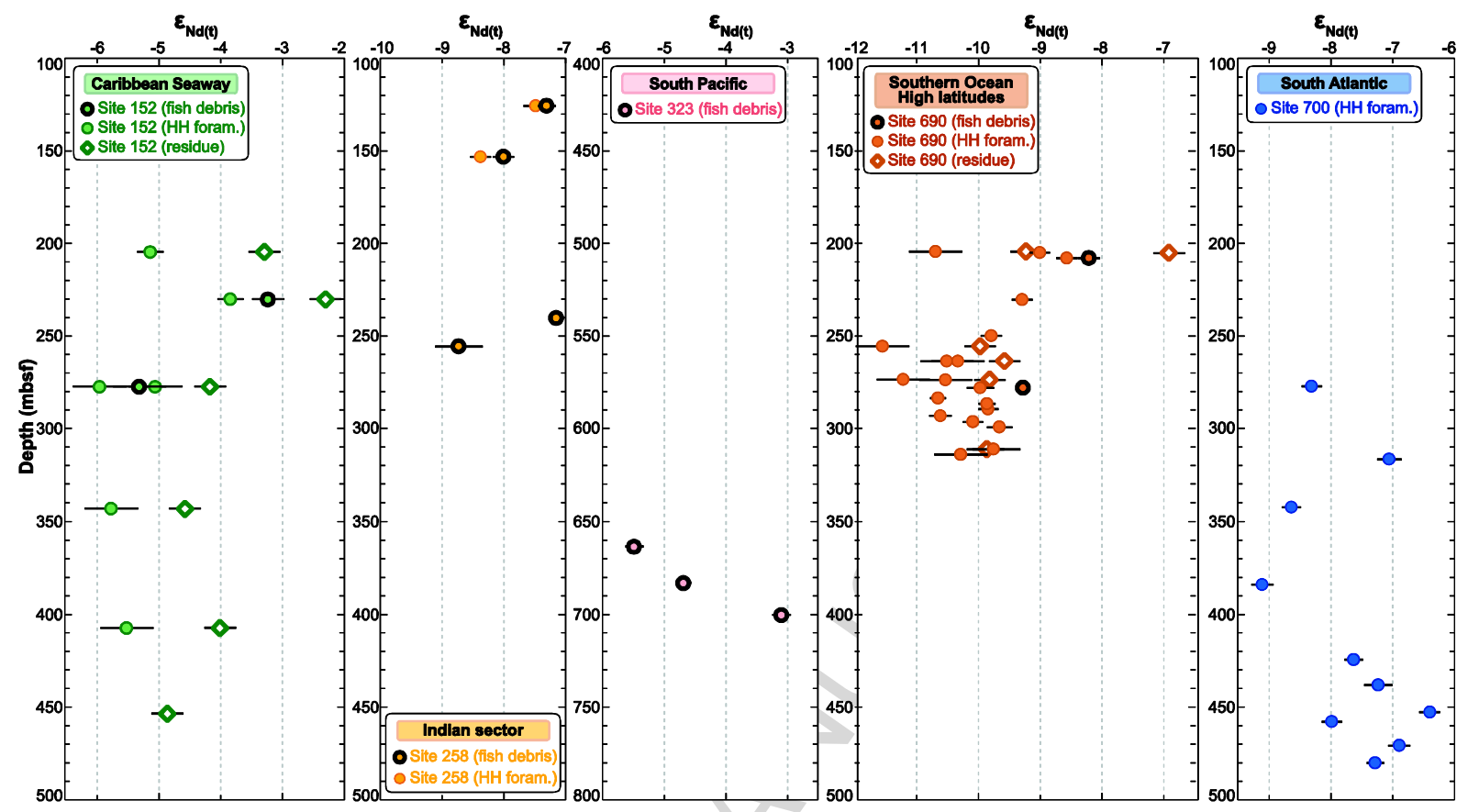

Figure 3 

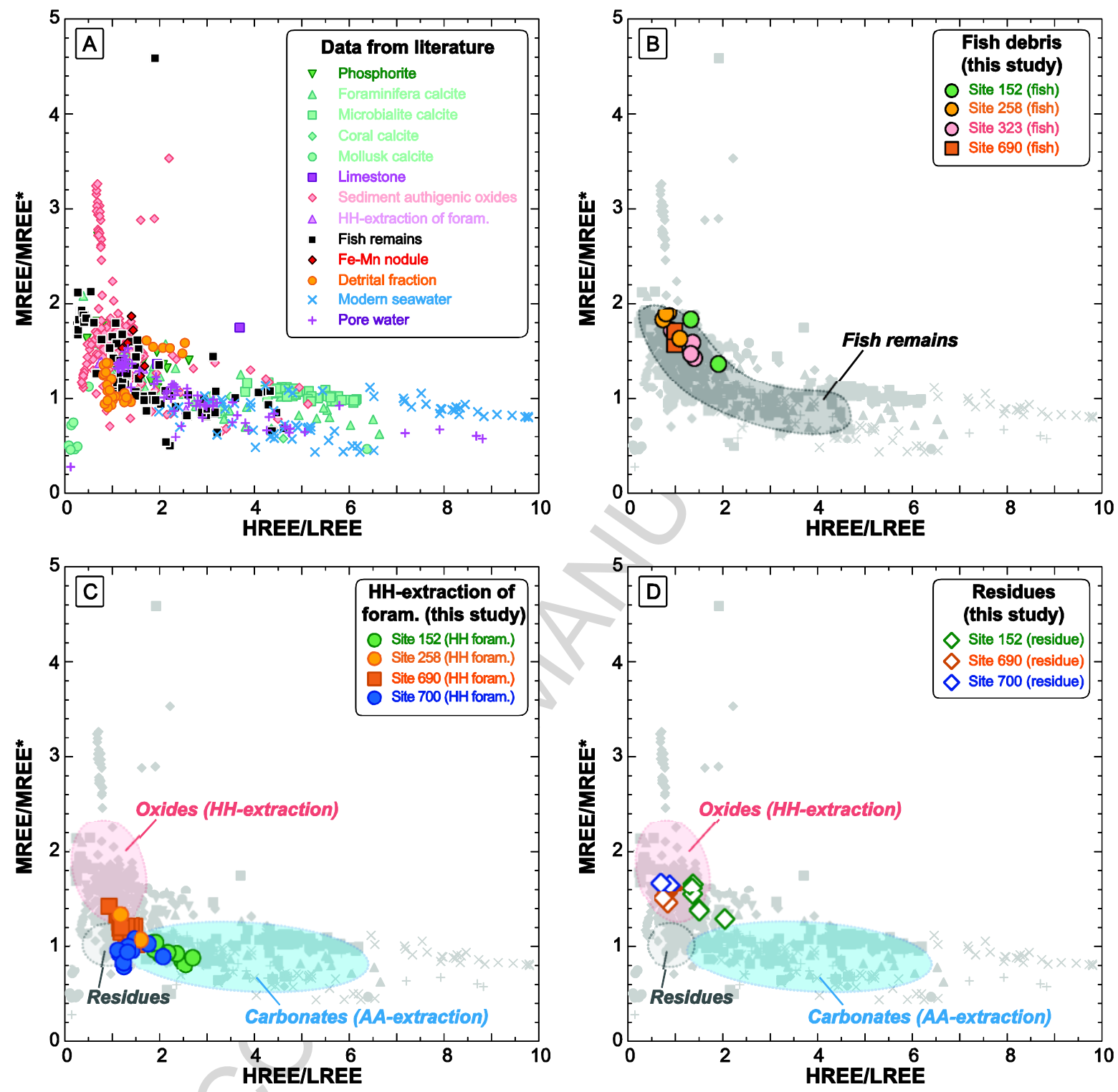

Figure 4 


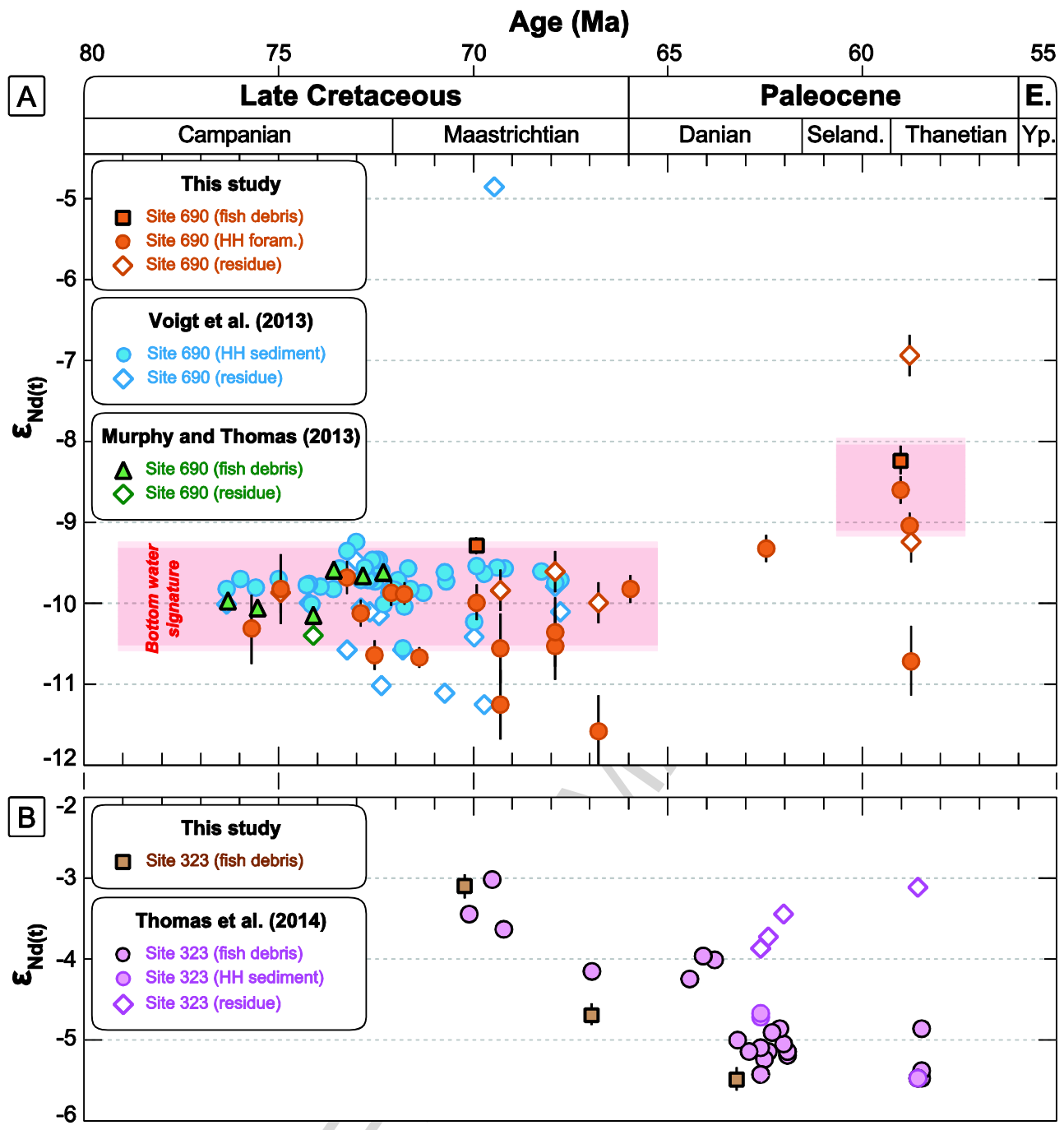

Figure 5 


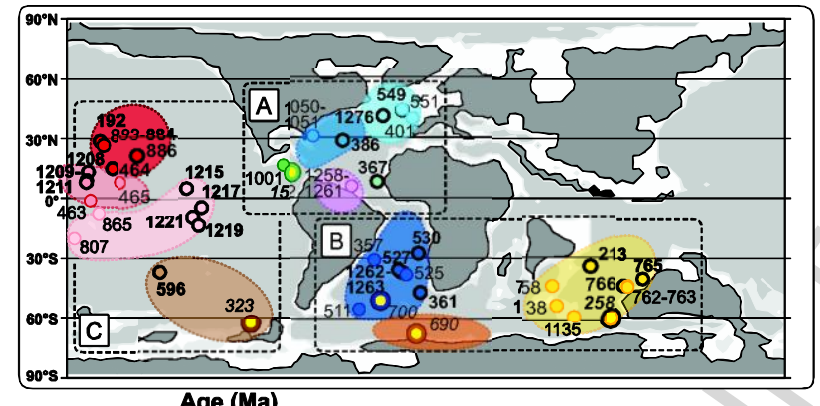

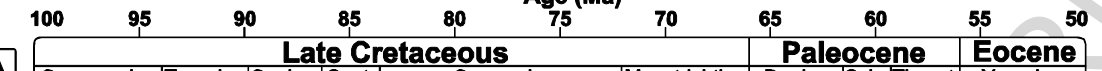

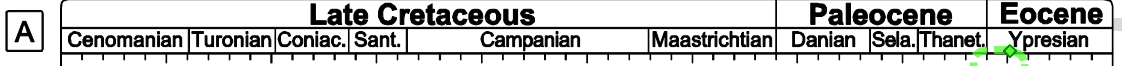
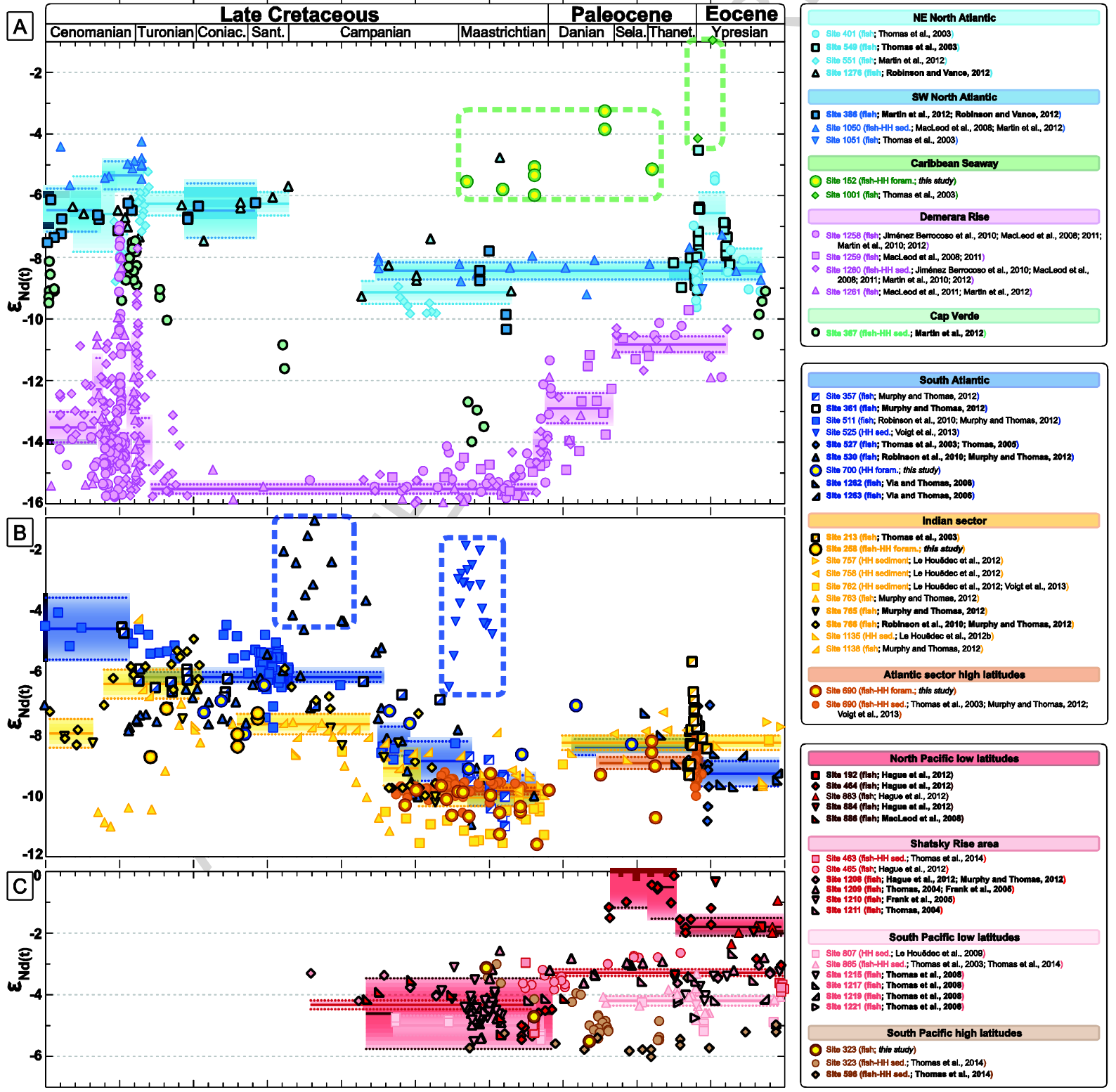

Figure 6 


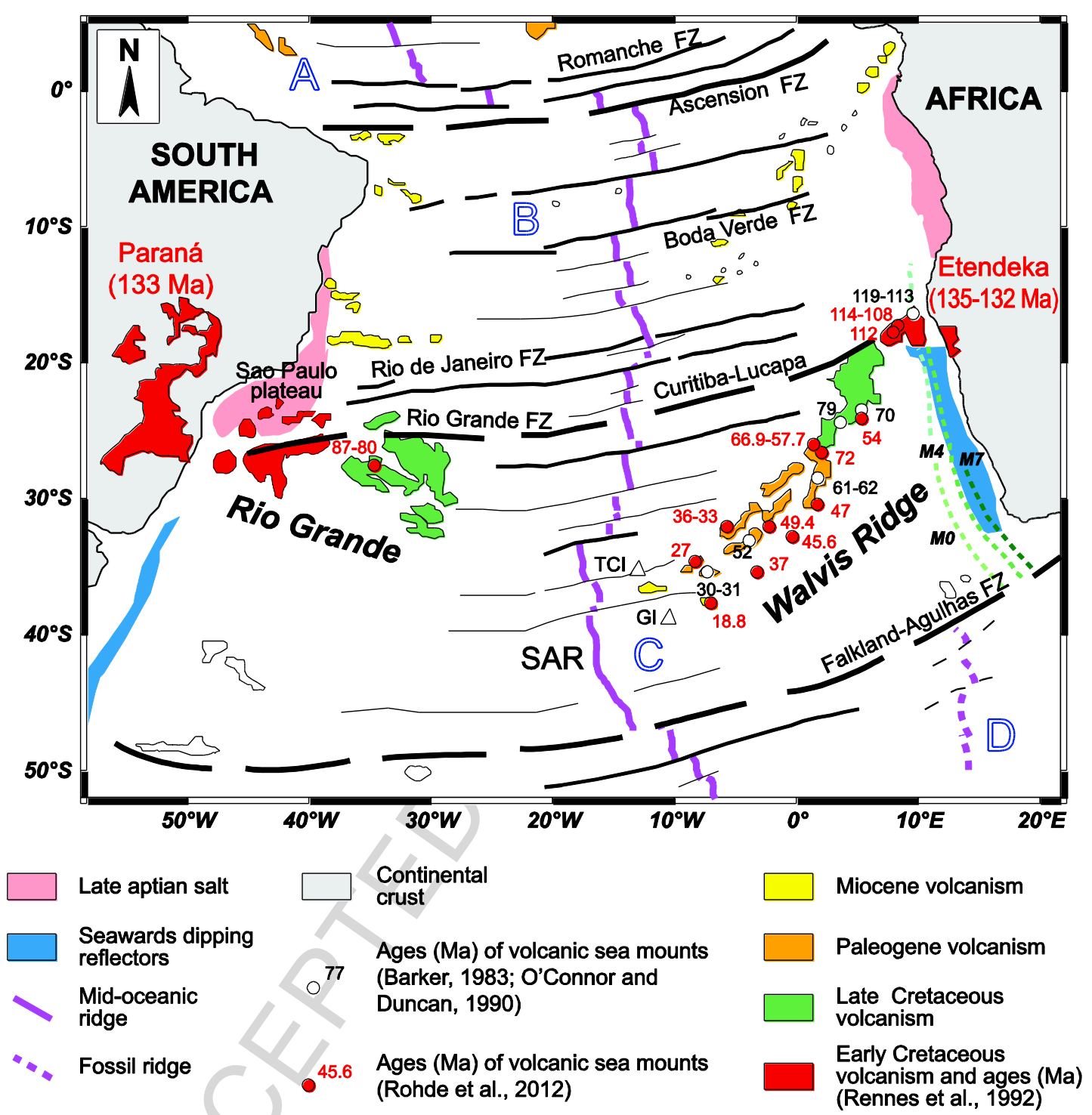

Figure 7 


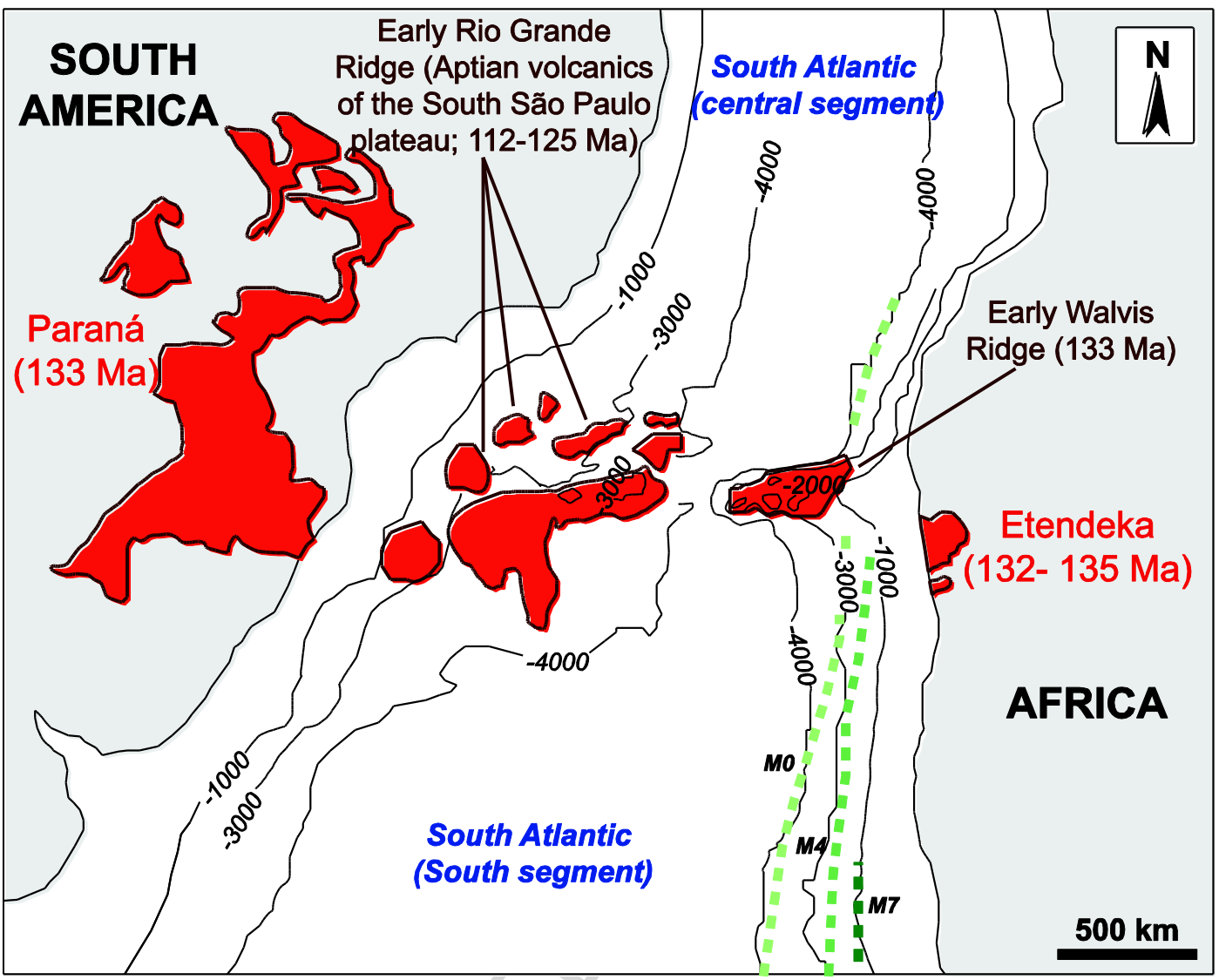

Figure 8 
Table I. Tabulated neodymium Nd isotopic data generated in this study.

\begin{tabular}{|c|c|c|c|c|c|c|c|c|c|c|c|}
\hline Sample ID ${ }^{1}$ & $\begin{array}{l}\text { Analytical } \\
\text { sample ID }\end{array}$ & Material & $\begin{array}{l}\text { Depth } \\
\text { (mbsf) }\end{array}$ & Age $(M a)^{2}$ & ${ }^{143} \mathrm{Nd} /{ }^{144} \mathrm{Nd}$ & error $^{3}$ & $\varepsilon_{\mathrm{Nd}(0)}{ }^{3}$ & $2 \sigma$ & ${ }^{147} \mathrm{Sm} /{ }^{144} \mathrm{Nd}^{4}$ & $\varepsilon_{\mathrm{Nd}(t)}$ & $2 \sigma$ \\
\hline \multicolumn{12}{|l|}{ Site 152} \\
\hline $152-9-1,98-100$ & $152-02$ & Fish debris & 229.99 & 62.19 & 0.512448 & 0.000013 & -3.70 & 0.26 & 0.1557 & -3.23 & 0.26 \\
\hline $152-14-1,120-122$ & $152-03$ & Fish debris & 277.21 & 66.97 & 0.512328 & 0.000022 & -6.04 & 0.43 & 0.1279 & -5.31 & 0.43 \\
\hline $152-6-3,50-52$ & $152-01$ & Foraminifera & 204.51 & 59.00 & 0.512337 & 0.000011 & -5.86 & 0.21 & 0.1192 & -5.13 & 0.21 \\
\hline $152-9-1,98-100$ & $152-02$ & Foraminifera & 229.99 & 62.19 & 0.512404 & 0.000011 & -4.56 & 0.21 & 0.1246 & -3.83 & 0.21 \\
\hline $152-14-1,120-122(1)$ & $152-03(1)$ & Foraminifera & 277.21 & 66.97 & 0.512284 & 0.000022 & -6.91 & 0.43 & 0.1014 & -5.95 & 0.43 \\
\hline $152-14-1,120-122(2)$ & $152-03(2)$ & Foraminifera & 277.21 & 66.97 & 0.512333 & 0.000022 & -5.96 & 0.43 & 0.1080 & -5.05 & 0.43 \\
\hline $152-16-1,120-122$ & $152-04$ & Foraminifera & 343.21 & 69.13 & 0.512296 & 0.000022 & -6.67 & 0.43 & 0.1102 & -5.76 & 0.43 \\
\hline $152-18-1,50-52$ & $152-05$ & Foraminifera & 407.51 & 71.56 & 0.512306 & 0.000022 & -6.47 & 0.43 & 0.1077 & -5.51 & 0.43 \\
\hline $152-6-3,50-52$ & RT 152-01 & Residue & 204.51 & 59.00 & 0.512438 & 0.000013 & -3.90 & 0.25 & 0.1346 & -3.29 & 0.25 \\
\hline $152-9-1,98-100$ & RT 152-02 & Residue & 229.99 & 62.19 & 0.512487 & 0.000013 & -2.95 & 0.25 & 0.1326 & -2.29 & 0.25 \\
\hline $152-14-1,120-122$ & RT 152-03 & Residue & 277.21 & 66.97 & 0.512388 & 0.000013 & -4.88 & 0.25 & 0.1298 & -4.16 & 0.25 \\
\hline $152-16-1,120-122$ & RT 152-04 & Residue & 343.21 & 69.13 & 0.512365 & 0.000013 & -5.32 & 0.25 & 0.1277 & -4.57 & 0.25 \\
\hline $152-18-1,50-52$ & RT 152-05 & Residue & 407.51 & 71.56 & 0.512391 & 0.000013 & -4.82 & 0.25 & 0.1238 & -4.00 & 0.25 \\
\hline 152-21-1, 90-92 & RT 152-06 & Residue & 453.91 & 75.36 & 0.512346 & 0.000013 & -5.70 & 0.25 & 0.1245 & -4.85 & 0.25 \\
\hline \multicolumn{12}{|l|}{ Site 258} \\
\hline $2625852 W$ 50-52 & $258-02$ & Fish debris & 125.51 & 85.70 & 0.512219 & 0.000007 & -8.17 & 0.14 & 0.1307 & -7.30 & 0.14 \\
\hline 262587 1W 107-109 & $258-07$ & Fish debris & 153.08 & 87.06 & 0.512179 & 0.000009 & -8.96 & 0.17 & 0.1237 & -8.00 & 0.17 \\
\hline 2625812 4W 114-116 & $258-14$ & Fish debris & 240.15 & 91.85 & 0.512228 & 0.000006 & -8.01 & 0.12 & 0.1359 & -7.15 & 0.12 \\
\hline $26258132 \mathrm{~W} 39,5-41,5$ & $258-21$ & Fish debris & 255.40 & 92.94 & 0.512143 & 0.000020 & -9.66 & 0.38 & 0.1306 & -8.73 & 0.38 \\
\hline $2625852 W$ 50-52 & $258-02$ & Foraminifera & 125.51 & 85.70 & 0.512206 & 0.000010 & -8.42 & 0.20 & 0.1240 & -7.48 & 0.20 \\
\hline 262587 1W 107-109 & $258-07^{*}$ & Foraminifera & 153.08 & 87.06 & 0.512155 & 0.000009 & -9.41 & 0.17 & 0.1165 & -8.38 & 0.17 \\
\hline \multicolumn{12}{|l|}{ Site 323} \\
\hline $323-15-6,70-72$ & $323-02$ & Fish debris & 663.21 & 63.24 & 0.512324 & 0.000007 & -6.13 & 0.14 & 0.1345 & -5.48 & 0.14 \\
\hline
\end{tabular}


323-17-6, 140-142

323-18-5, 110-112

\section{Site 690}

113 690C 11X 3W 60-62

113 690C 18X 5W 50-52

113 690C 11X 1W 20-22

113 690C 11X 1W 70-72

113 690C 11X 3W 60-62

113 690C 13X 5W 67-69

113 690C 15X 5W 70-72

113 690C 16X 2W 130-132

113 690C 17X 2W 10-12 (1)

113 690C 17X 2W 10-12 (2)

113 690C 18X 2W 50-52 (1)

113 690C 18X 2W 50-52 (2)

113 690C 18X 5W 50-52

113 690C 19X 2W 70-72

113 690C 19X 4W 70-72

113 690C 19X 6W 70-72

113 690C 20X 2W 66-68

113 690C 20X 4W 70-72

113 690C 20X 6W 70-72

113 690C 22X 1W 70-71

113 690C 22X 3W 70-72

113 690C 11X 1W 20-22

113 690C 11X 1W 70-72

113 690C 16X 2W 130-132

113 690C 17X 2W 10-12

113 690C 18X 2W 50-52

113 690C 22X 1W 70-71

\begin{tabular}{|c|c|c|c|c|c|c|c|c|c|c|}
\hline $323-07$ & Fish debris & 682.91 & 66.99 & 0.512367 & 0.000007 & -5.29 & 0.13 & 0.1424 & -4.68 & 0.13 \\
\hline 323-15 & Fish debris & 700.11 & 70.25 & 0.512440 & 0.000008 & -3.86 & 0.15 & 0.1280 & -3.10 & 0.15 \\
\hline $690-08$ & Fish debris & 207.81 & 59.04 & 0.512185 & 0.000009 & -8.83 & 0.18 & 0.1336 & -8.21 & 0.18 \\
\hline $690-25$ & Fish debris & 277.91 & 69.93 & 0.512123 & 0.000005 & -10.05 & 0.10 & 0.1265 & -9.27 & 0.10 \\
\hline $690-01$ & Foraminifera & 204.41 & 58.77 & 0.512051 & 0.000022 & -11.44 & 0.43 & 0.1167 & -10.69 & 0.43 \\
\hline $690-02$ & Foraminifera & 204.91 & 58.81 & 0.512141 & 0.000008 & -9.70 & 0.16 & 0.1239 & -9.01 & 0.16 \\
\hline $690-08$ & Foraminifera & 207.81 & 59.04 & 0.512162 & 0.000009 & -9.28 & 0.17 & 0.1213 & -8.57 & 0.17 \\
\hline $690-15^{*}$ & Foraminifera & 230.28 & 62.51 & 0.512125 & 0.000008 & -10.00 & 0.17 & 0.1260 & -9.29 & 0.17 \\
\hline $690-21$ & Foraminifera & 249.61 & 66.00 & 0.512097 & 0.000009 & -10.56 & 0.17 & 0.1230 & -9.79 & 0.17 \\
\hline $690-22$ & Foraminifera & 255.31 & 66.82 & 0.512002 & 0.000022 & -12.41 & 0.43 & 0.1135 & -11.55 & 0.43 \\
\hline $690-23(1)$ & Foraminifera & 263.41 & 67.93 & 0.512058 & 0.000022 & -11.32 & 0.43 & 0.1211 & -10.51 & 0.43 \\
\hline $690-23(2)$ & Foraminifera & 263.41 & 67.93 & 0.512066 & 0.000022 & -11.16 & 0.43 & 0.1179 & -10.33 & 0.43 \\
\hline $690-24(1)$ & Foraminifera & 273.41 & 69.31 & 0.512056 & 0.000022 & -11.35 & 0.43 & 0.1213 & -10.53 & 0.43 \\
\hline $690-24(2)$ & Foraminifera & 273.41 & 69.31 & 0.512020 & 0.000022 & -12.06 & 0.43 & 0.1177 & -11.22 & 0.43 \\
\hline $690-25$ & Foraminifera & 277.91 & 69.93 & 0.512085 & 0.000011 & -10.79 & 0.22 & 0.1215 & -9.97 & 0.22 \\
\hline $690-26$ & Foraminifera & 283.31 & 71.42 & 0.512049 & 0.000007 & -11.48 & 0.13 & 0.1215 & -10.65 & 0.13 \\
\hline $690-27$ & Foraminifera & 286.31 & 71.79 & 0.512089 & 0.000007 & -10.71 & 0.14 & 0.1201 & -9.86 & 0.14 \\
\hline $690-28^{*}$ & Foraminifera & 289.31 & 72.14 & 0.512091 & 0.000008 & -10.67 & 0.16 & 0.1223 & -9.84 & 0.16 \\
\hline $690-29^{*}$ & Foraminifera & 292.97 & 72.56 & 0.512051 & 0.000009 & -11.45 & 0.18 & 0.1228 & -10.61 & 0.18 \\
\hline $690-30^{*}$ & Foraminifera & 296.01 & 72.92 & 0.512078 & 0.000008 & -10.93 & 0.16 & 0.1217 & -10.09 & 0.16 \\
\hline $690-31^{*}$ & Foraminifera & 299.01 & 73.26 & 0.512102 & 0.000010 & -10.45 & 0.20 & 0.1271 & -9.65 & 0.20 \\
\hline $690-34$ & Foraminifera & 310.81 & 74.98 & 0.512091 & 0.000022 & -10.68 & 0.43 & 0.1192 & -9.79 & 0.43 \\
\hline $690-35$ & Foraminifera & 313.81 & 75.71 & 0.512066 & 0.000022 & -11.16 & 0.43 & 0.1215 & -10.28 & 0.43 \\
\hline RT 690-01 & Residue & 204.41 & 58.77 & 0.512129 & 0.000013 & -9.94 & 0.25 & 0.1217 & -9.22 & 0.25 \\
\hline RT 690-02 & Residue & 204.91 & 58.81 & 0.512247 & 0.000013 & -7.63 & 0.25 & 0.1204 & -6.91 & 0.25 \\
\hline RT 690-22 & Residue & 255.31 & 66.82 & 0.512091 & 0.000013 & -10.68 & 0.25 & 0.1309 & -9.97 & 0.25 \\
\hline RT 690-23 & Residue & 263.41 & 67.93 & 0.512106 & 0.000013 & -10.38 & 0.25 & 0.1206 & -9.57 & 0.25 \\
\hline RT 690-24 & Residue & 273.41 & 69.31 & 0.512094 & 0.000013 & -10.61 & 0.25 & 0.1232 & -9.82 & 0.25 \\
\hline RT 690-34 & Residue & 310.81 & 74.98 & 0.512088 & 0.000013 & -10.74 & 0.25 & 0.1183 & -9.84 & 0.25 \\
\hline
\end{tabular}




\section{Site 700}

114 700B 30R 1W 79-81

$\begin{array}{ccc}700-03^{*} & \text { Foraminifera } & 276.80 \\ 700-08 & \text { Foraminifera } & 316.23 \\ 700-12 & \text { Foraminifera } & 342.21 \\ 700-15^{*} & \text { Foraminifera } & 384.02 \\ 700-19^{*} & \text { Foraminifera } & 424.50 \\ 700-22 & \text { Foraminifera } & 438.21 \\ 700-27 & \text { Foraminifera } & 452.71 \\ 700-32 & \text { Foraminifera } & 457.72 \\ 700-36 & \text { Foraminifera } & 470.70\end{array}$

$\begin{array}{lll}60.39 & 0.512175 & 0.000008 \\ 64.18 & 0.512237 & 0.000010 \\ 67.82 & 0.512153 & 0.000008 \\ 71.40 & 0.512124 & 0.000009 \\ 75.41 & 0.512196 & 0.000008 \\ 76.78 & 0.512219 & 0.000012 \\ 85.26 & 0.512252 & 0.000009 \\ 86.56 & 0.512171 & 0.000008 \\ 88.17 & 0.512219 & 0.000009 \\ 89.35 & 0.512202 & 0.000007\end{array}$

$-9.02$

\subsection{6}

0.1233

$-8.31$

0.16

114 700B 34R 2W 72-73,5

114 700B 38R 5W 70-71,5

114 700B 43R 1W 101,5-103

114 700B 48R 2W 49,5-51

114 700B 49R 5W 20,5-22

114 700B 51R 2W 20-21,5

700-39

Foraminifera

480.22

0.512202

0.000007

$-9.46$

$$
-10.02
$$

0.19

0.1221

$-7.05$

0.19

114 700B 53R 1W 69-70,5

114 700B 54R 1W 71-72,5

A '(1)' or '(2)' at the end of the sample ID indicates a sample duplicate. An asterisk signals a

$\left.{ }^{3} \varepsilon_{\mathrm{Nd}(0)}==\left.^{143} \mathrm{Nd}^{1 / 44} \mathrm{Nd}_{\text {measured }}\right|^{143} \mathrm{Nd} /{ }^{144} \mathrm{Nd}_{\text {CHUR }}-1\right] \times 10^{4}$, where ${ }^{143} \mathrm{Nd} /{ }^{144} \mathrm{Nd} d_{\text {HUR }}=0.512630$ (Bouvier et al., 2008).

${ }^{4}{ }^{147} \mathrm{Sm} /{ }^{144} \mathrm{Nd}$ was calculated as $\mathrm{Sm} / \mathrm{Nd}^{\star} 0.6049$ 
Table II. Tabulated REEs data generated in this study.

\begin{tabular}{|c|c|c|c|c|c|c|c|c|c|c|c|c|c|c|c|c|c|c|}
\hline Sample ID ${ }^{1}$ & $\begin{array}{c}\text { Analytical } \\
\text { sample ID }{ }^{1,2}\end{array}$ & Material & $\begin{array}{l}\text { Age } \\
(\mathrm{Ma})^{3}\end{array}$ & $\begin{array}{c}\text { La } \\
(\mathrm{ppm})\end{array}$ & $\begin{array}{c}\mathrm{Ce} \\
(\mathrm{ppm})\end{array}$ & $\begin{array}{c}\mathrm{Pr} \\
(\mathrm{ppm})\end{array}$ & $\begin{array}{c}\mathbf{N d} \\
(\mathrm{ppm})\end{array}$ & $\begin{array}{c}\text { Sm } \\
\text { (ppm) }\end{array}$ & $\begin{array}{c}\text { Eu } \\
(\mathrm{ppm})\end{array}$ & $\begin{array}{c}\text { Gd } \\
\text { (ppm) }\end{array}$ & $\begin{array}{c}\text { Tb } \\
(\mathrm{ppm})\end{array}$ & $\begin{array}{c}\text { Dy } \\
\text { (ppm) }\end{array}$ & $\begin{array}{c}\text { Ho } \\
\text { (ppm) }\end{array}$ & $\begin{array}{c}\mathrm{Er} \\
(\mathrm{ppm})\end{array}$ & $\begin{array}{c}\text { Yb } \\
(\mathrm{ppm})\end{array}$ & $\begin{array}{c}\text { Lu } \\
(\mathrm{ppm})\end{array}$ & $\begin{array}{c}\text { HREE/L } \\
\text { REE }^{4}\end{array}$ & $\begin{array}{l}\text { MREE/ } \\
\text { MREE }^{\star 4}\end{array}$ \\
\hline \multicolumn{19}{|l|}{ Site 152} \\
\hline $152-9-1,98-100$ & $152-02$ & Fish debris & 62.19 & 380.37 & 241.48 & 78.83 & 260.19 & 66.97 & 18.31 & 83.46 & 13.00 & 83.26 & 19.03 & 56.32 & 47.28 & 6.58 & 1.89 & 1.37 \\
\hline $152-14-1,120-122$ & $152-03$ & Fish debris & 66.97 & 246.23 & 104.28 & 69.19 & 328.43 & 69.47 & 17.45 & 89.50 & 12.22 & 72.69 & 15.83 & 42.10 & 27.51 & 4.25 & 1.33 & 1.81 \\
\hline $152-6-3,50-52$ & $152-01$ & Foraminifera & 59.00 & 2.76 & 2.38 & 0.49 & 2.77 & 0.44 & 0.08 & 0.49 & 0.08 & 0.51 & 0.12 & 0.39 & 0.50 & 0.08 & 2.49 & 0.86 \\
\hline $152-6-3,50-52$ & $152-01$ & Foraminifera & 59.00 & 4.15 & 2.71 & 0.68 & 2.74 & 0.54 & 0.14 & 0.62 & 0.10 & 0.65 & 0.15 & 0.46 & 0.56 & 0.09 & 2.20 & 0.94 \\
\hline $152-9-1,98-100$ & $152-02$ & Foraminifera & 62.19 & 5.77 & 3.59 & 0.96 & 3.98 & 0.82 & 0.21 & 0.97 & 0.15 & 1.04 & 0.24 & 0.76 & 0.98 & 0.16 & 2.72 & 0.89 \\
\hline $152-14-1,120-122(1)$ & $152-03(1)$ & Foraminifera & 66.97 & 7.10 & 2.44 & 0.97 & 4.45 & 0.75 & 0.18 & 0.90 & 0.15 & 0.99 & 0.24 & 0.76 & 0.84 & 0.13 & 2.04 & 0.92 \\
\hline $152-14-1,120-122(2)$ & $152-03(2)$ & Foraminifera & 66.97 & 7.83 & 2.58 & 1.05 & 4.59 & 0.82 & 0.21 & 1.03 & 0.16 & 1.05 & 0.26 & 0.79 & 0.85 & 0.13 & 1.91 & 0.97 \\
\hline $152-16-1,120-122$ & $152-04$ & Foraminifera & 69.13 & 10.34 & 3.23 & 1.47 & 6.47 & 1.18 & 0.29 & 1.49 & 0.23 & 1.53 & 0.37 & 1.11 & 1.15 & 0.17 & 1.89 & 1.04 \\
\hline $152-18-1,50-52$ & $152-05$ & Foraminifera & 71.56 & 5.32 & 2.35 & 0.72 & 3.14 & 0.56 & 0.14 & 0.73 & 0.11 & 0.76 & 0.18 & 0.56 & 0.56 & 0.08 & 1.87 & 1.03 \\
\hline $152-21-1,90-92$ & $152-06$ & Foraminifera & 75.36 & 3.90 & 1.85 & 0.52 & 2.61 & 0.42 & 0.10 & 0.57 & 0.09 & 0.60 & 0.15 & 0.45 & 0.44 & 0.07 & 1.95 & 1.04 \\
\hline $152-6-3,50-52$ & RT 152-01 & Residue fraction & 59.00 & 7.09 & 8.48 & 1.88 & 8.22 & 1.83 & 0.34 & 1.97 & 0.29 & 1.77 & 0.37 & 1.04 & 0.84 & 0.12 & 1.41 & 1.53 \\
\hline $152-9-1,98-100$ & RT 152-02 & Residue fraction & 62.19 & 16.89 & 17.44 & 3.43 & 14.58 & 3.20 & 1.65 & 3.60 & 0.54 & 3.37 & 0.75 & 2.11 & 1.83 & 0.26 & 1.54 & 1.37 \\
\hline $152-14-1,120-122$ & RT 152-03 & Residue fraction & 66.97 & 38.33 & 22.71 & 9.55 & 43.37 & 9.31 & 2.22 & 11.02 & 1.56 & 9.54 & 2.04 & 5.38 & 4.00 & 0.64 & 1.35 & 1.62 \\
\hline $152-16-1,120-122$ & RT 152-04 & Residue fraction & 69.13 & 23.78 & 12.60 & 5.67 & 25.99 & 5.49 & 1.31 & 6.98 & 0.96 & 5.86 & 1.26 & 3.37 & 2.50 & 0.37 & 1.37 & 1.66 \\
\hline $152-18-1,50-52$ & RT 152-05 & Residue fraction & 71.56 & 9.86 & 4.76 & 1.75 & 7.66 & 1.57 & 0.78 & 2.06 & 0.28 & 1.75 & 0.39 & 1.10 & 0.93 & 0.16 & 1.54 & 1.36 \\
\hline $152-21-1,90-92$ & RT 152-06 & Residue fraction & 75.36 & & 4.18 & 1.43 & 6.40 & 1.32 & 0.30 & 1.95 & 0.26 & 1.66 & 0.38 & 1.11 & 0.99 & 0.19 & 2.08 & 1.28 \\
\hline \multicolumn{19}{|l|}{ Site 258} \\
\hline 262585 2W 50-52 & $258-02$ & Fish debris & 85.70 & 1997.05 & 1737.44 & 605.03 & 2504.69 & 541.08 & 122.32 & 532.44 & 77.01 & 438.01 & 86.35 & 216.93 & 130.35 & 16.49 & 0.75 & 1.81 \\
\hline 262587 1W 107-109 & $258-07$ & Fish debris & 87.06 & 2020.93 & 971.41 & 473.58 & 1934.68 & 395.75 & 94.62 & 476.58 & 67.87 & 414.07 & 88.64 & 233.57 & 161.66 & 23.12 & 1.10 & 1.62 \\
\hline $26258124 \mathrm{~W} 114-116$ & $258-14$ & Fish debris & 91.85 & 2101.18 & 2511.37 & 646.91 & 2745.62 & 616.93 & 142.03 & 645.67 & 91.27 & 518.86 & 102.79 & 256.27 & 160.61 & 21.95 & 0.87 & 1.88 \\
\hline 2625813 2W 39,5-41,5 & $258-21$ & Fish debris & 92.94 & 449.80 & 488.07 & 113.30 & 448.91 & 96.92 & 23.15 & 108.75 & 15.79 & 95.04 & 18.88 & 47.15 & 26.83 & 3.44 & 0.81 & 1.87 \\
\hline $2625852 W 50-52$ & $258-02$ & Foraminifera & 85.70 & 12.14 & 6.59 & 2.67 & 11.27 & 2.31 & 0.55 & 2.42 & 0.34 & 2.01 & 0.42 & 1.14 & 1.05 & 0.16 & 1.18 & 1.33 \\
\hline 262587 1W 107-109 & $258-07^{*}$ & Foraminifera & 87.06 & 10.59 & 5.89 & 1.77 & 7.01 & 1.35 & 0.33 & 1.51 & 0.24 & 1.54 & 0.34 & 1.01 & 1.07 & 0.16 & 1.63 & 1.07 \\
\hline
\end{tabular}

Site 323 
323-15-6, 70-72

323-17-6, 140-142

323-18-2, 112-114

323-18-5, 110-112

\section{Site 690}

$690 \mathrm{C}-11 \mathrm{X}-3,60-62$

$690 \mathrm{C}-18 \mathrm{X}-5,50-52$

$690 \mathrm{C}-11 \mathrm{X}-1,20-22$

690C-11X-1, 70-72

690C-11X-3, 60-62

690C-13X-5, 67-69

690C-15X-5, 70-72

690C-16X-2, 130-132

690C-17X-2, 10-12 (1)

690C-17X-2, 10-12 (2)

690C-18X-2, 50-52 (1)

$690 \mathrm{C}-18 \mathrm{X}-2,50-52$ (2)

$690 \mathrm{C}-18 \mathrm{X}-5,50-52$

690C-19X-2, 70-72

690C-19X-4, 70-72

$690 \mathrm{C}-19 \mathrm{X}-6,70-72$

690C-20X-2, 66-68

690C-20X-4, 70-72

$690 \mathrm{C}-20 \mathrm{X}-6,70-72$

690C-22X-1, 70-71

690C-22X-3, 70-72

$690 \mathrm{C}-11 \mathrm{X}-1,20-22$

690C-11X-1, 70-72

690C-11X-3, 60-62

690C-16X-2, 130-132

690C-17X-2, 10-12
323-02

323-07

323-09

323-15

690-08

690-25

690-01

690-02

690-08

$690-15^{*}$

690-21

690-22

690-23 (1)

690-23 (2)

690-24 (1)

690-24 (2)

690-25

690-26

690-27

$690-28^{*}$

690-29*

690-30*

690-31*

690-34

690-35

RT 690-01

RT 690-02

RT 690-08 (HH)

RT 690-22

RT 690-23
Fish debris

Fish debris

Fish debris

Fish debris

Fish debris

Fish debris

Foraminifera

Foraminifera

Foraminifera

Foraminifera

Foraminifera

Foraminifera

Foraminifera

Foraminifera

Foraminifera

Foraminifera

Foraminifera

Foraminifera

Foraminifera

Foraminifera

Foraminifera

Foraminifera

Foraminifera

Foraminifera

Foraminifera

Residue fraction $58.81 \quad 17.56$

Residue fraction $\quad 59.04 \quad 51.88$

Residue fraction $\quad 66.82 \quad 63.50$

Residue fraction

$62.51 \quad 9.48$

$66.00 \quad 15.30$

6.82

$67.93 \quad 7.40$

$69.31 \quad 7.77$

$69.31 \quad 9.6$

$72.92 \quad 7.85$ $\begin{array}{llllll}63.24 & 722.79 & 482.97 & 210.72 & 830.28 & 184.59\end{array}$

$\begin{array}{llllll}66.99 & 257.97 & 192.00 & 65.25 & 241.08 & 56.74\end{array}$

$\begin{array}{lllllll}69.40 & 3284.84 & 5334.92 & 944.93 & 3918.01 & 840.50\end{array}$

$\begin{array}{llllll}70.25 & 2013.89 & 1411.65 & 507.43 & 2105.59 & 445.42\end{array}$

$\begin{array}{llllll}59.04 & 1418.06 & 2268.36 & 419.72 & 1698.56 & 375.01\end{array}$

$\begin{array}{lllllllll}58.77 & 5.29 & 10.40 & 1.19 & 5.44 & 1.05 & 0.23 & 1.06\end{array}$

$14.52 \quad 2.32$

$\begin{array}{llll}69.93 & 14.67 & 14.51 & 3.00\end{array}$

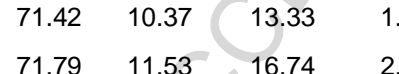

$\begin{array}{llll}72.14 & 8.70 & 11.05 & 1.74\end{array}$

$\begin{array}{llll}72.56 & 7.39 & 10.47 & 1.42\end{array}$

$11.23 \quad 1.42$

$23.05 \quad 2.13$

$61.08 \quad 10.46$

$45.03 \quad 6.48 \quad 24.57$

$96.01 \quad 14.84 \quad 60.4$

$85.58 \quad 19.58 \quad 82.10$

$36.93 \quad 11.44 \quad 45.19$

$43.45 \quad 184.43$
163.74

56.82

31.70

80.50

58

$\begin{array}{ll}58.25 & 7.68\end{array}$

0.93

1.70

$\begin{array}{llllllll}194.79 & 915.05 & 145.27 & 900.38 & 184.89 & 492.57 & 395.48 & 53.53\end{array}$

1.36

1.43

1.58

1.47

RT $690-23$

\begin{abstract}
$67.93 \quad 25.50$
\end{abstract}
11.44 
690C-18X-2, 50-52

RT 690-24

RT 690-24 (HH)

Residue fraction

$\begin{array}{ll}69.31 \quad 26.22 \\ 69.31 & 71.77\end{array}$

$42.17 \quad 11.37$

45.54

$9.27 \quad 1.99$

$690 \mathrm{C}-22 \mathrm{X}-1,70-71$

RT 690-34

Residue fraction

$69.31 \quad 71.77$

86.87

9.21

79.60

17.09

\begin{tabular}{l|l}
1.99 & 8.76 \\
4.34 & 17.31 \\
2.30 & 9.90
\end{tabular}

1.28
2.49
1.46

7.40

1.48

3.80

2.79

0.38

0.91

1.62

\section{Site 700}

700B-30R-1, 79-81

700B-34R-2, 72-73,5

700B-38R-5, 70-71,5

\section{0-03*}

Foraminifera

$60.39 \quad 6.34$

()

700B-43R-1, 101,5-103

700B-48R-2, 49,5-51

700B-49R-5, 20,5-22

700B-51R-2, 20-21,5

700B-51R-5, 71,5-73

700B-53R-1, 69-70,5

700B-54R-1, 71-72,5

700B-34R-2, 72-73,5

700-08

Foraminifera

700-12

Foraminifera

$\begin{array}{ll}64.18 \quad 8.88 \\ 67.82 & 10.28\end{array}$

$11.88 \quad 1.03$

$700-15^{\star}$

$700-19^{*}$

700-22

$700-27$

700-32

Foraminifera

$\begin{array}{ll}67.82 & 10.28\end{array}$

Foraminifera

$\begin{array}{ll}71.40 & 15.43\end{array}$

$17.28 \quad 1.46$

Foraminifera

$\begin{array}{ll}75.41 & 8.54\end{array}$

$10.62 \quad 1.80$

700-36

Foraminifera

$11.83-2.41$

Foraminifera

$85.26 \quad 12.09$

700-39

Foraminifera

$86.56 \quad 11.46$

$21.80 \quad 2.07$

700B-43R-1, 101,5-103

Foraminifera

$88.17 \quad 15.52$

21.56

700-08 (HH) Residue fraction $\quad 64.18 \quad 28.95$

$\begin{array}{llll}1.80 & 6.16 & 1.11 & 0.25\end{array}$

$\begin{array}{llllll}24.47 & 1.88 & 6.92 & 1.09 & 0.26\end{array}$

$\begin{array}{llllll}24.86 & 2.17 & 7.17 & 1.21 & 0.28\end{array}$

$\begin{array}{lllll}62.83 & 9.03 & 37.71 & 8.14 & 2.21\end{array}$

RT 700-15 (HH) Residue fraction $71.40 \quad 64.37$

$\begin{array}{lll}78.52 & 18.71 \quad 79.28\end{array}$

16.97

4.07

'A '(1)' or '(2)' at the end of the sample ID indicates a sample duplicate. An asterisk signals a foraminifera sample for which planktonic species were mixed with benthic species.

2 ' $\mathrm{HH}$ ' indicate a modified protocol for REE extraction from the detritarion, to avoid contamination by authigenic marine oxides
3 'Details of the age model are given in the Supplementary information.

Details of the age model are given in the Supplementary information.

MREE $=(\mathrm{Gd}) \mathrm{N}+(\mathrm{Tb}) \mathrm{N}+(\mathrm{Dy}) \mathrm{N}$, and MREE* ${ }^{*}(\mathrm{HREE}+\mathrm{LREE}) / 2$. PAAS values after Taylor and McLennan (1985). 